NBER WORKING PAPER SERIES

\title{
SCIENTIFIC EDUCATION AND INNOVATION: FROM TECHNICAL DIPLOMAS TO UNIVERSITY STEM DEGREES
}

\author{
Nicola Bianchi \\ Michela Giorcelli \\ Working Paper 25928 \\ http://www.nber.org/papers/w25928 \\ NATIONAL BUREAU OF ECONOMIC RESEARCH \\ 1050 Massachusetts Avenue \\ Cambridge, MA 02138 \\ June 2019
}

We thank Ran Abramitzky, Nick Bloom, Leah Boustan, Mary Burke, Annamaria Conti, Dora Costa, Pascaline Dupas, Caroline Hoxby, Ben Jones, Maurizio Mazzocco, Melanie Morten, Petra Moser, Giovanni Peri, and seminar and conference participants at the ASSA meeting, Barcelona GSE, Collegio Carlo Alberto, EHA meeting, INPS, MEA meeting, Modena, NBER, Northwestern, NUS, Searle Center, Stanford, UCLA, and UC-Riverside for helpful comments. Mohammad Zuhad Hai provided excellent research assistance. We thank Istituto Nazionale Previdenza Sociale (INPS) for making the social security data available through the VisitINPS program. We gratefully acknowledge financial support from the Stanford Europe Center and the Stanford Center for International Development. The views expressed herein are those of the authors and do not necessarily reflect the views of the National Bureau of Economic Research.

NBER working papers are circulated for discussion and comment purposes. They have not been peer-reviewed or been subject to the review by the NBER Board of Directors that accompanies official NBER publications.

(C) 2019 by Nicola Bianchi and Michela Giorcelli. All rights reserved. Short sections of text, not to exceed two paragraphs, may be quoted without explicit permission provided that full credit, including $(\odot)$ notice, is given to the source. 
Scientific Education and Innovation: From Technical Diplomas to University STEM Degrees Nicola Bianchi and Michela Giorcelli

NBER Working Paper No. 25928

June 2019

JEL No. I21,I25,I26,I28,J24,O30

\begin{abstract}
$\underline{\text { ABSTRACT }}$
This paper studies the effects of university STEM education on innovation and labor market outcomes by exploiting a change in enrollment requirements in Italian STEM majors. Universitylevel scientific education had two direct effects on the development of patents by students who had acquired a STEM degree. First, the policy changed the direction of their innovation. Second, it allowed these individuals to reach top positions within firms and be more involved in the innovation process. STEM degrees, however, also changed occupational sorting. Some higherachieving individuals used STEM degrees to enter jobs that required university-level education, but did not focus on patenting.
\end{abstract}

\author{
Nicola Bianchi \\ Kellogg School of Management \\ Northwestern University \\ 2211 Campus Drive \\ Evanston, IL 60208 \\ and NBER \\ nicola.bianchi@kellogg.northwestern.edu \\ Michela Giorcelli \\ Department of Economics \\ University of California at Los Angeles \\ Bunche Hall 9262 \\ Los Angeles, CA 90095 \\ and NBER \\ mgiorcelli@econ.ucla.edu
}

An online appendix is available at: $\mathrm{http} / / \mathrm{www}$.nber.org/data-appendix/w25928 


\section{Introduction}

Economists and policy makers have been studying the drivers of aggregate production for decades. Early research established that increases in the stock of capital and labor could account for only less than half of total productivity growth (Copeland, 1937; Solow, 1957). In a seminal paper, Solow (1957) labels the residual component as technical change, which includes any activity that leads to improvements in capital, labor, or other factors in the aggregate production function. Subsequent empirical research has further documented how investments in innovation (for example, R\&D and patenting) are positively correlated with firm-level productivity, reinforcing the idea that innovation is a central driver of economic growth (Griliches, 1996; Hall, 2011; Peri, Shih and Sparber, 2015).

From a policy perspective, then, it is important to study what factors are able to spur individual innovation and, as a consequence, increase aggregate production. In recent years, policy makers have focused on the role played by education. Many developed countries, in fact, fear that their school systems do not produce an adequate number of STEM (science, technology, engineering, and math) graduates to address the future needs of the economy (Carnevale, Smith and Melton, 2011; PCAST, 2012). In 2012, for example, the US President's Council of the Advisors on Science and Technology (PCAST) highlighted the "need for approximately 1 million more STEM professionals than the U.S. will produce at the current rate over the next decade if the country is to retain its historical preeminence in science and technology (PCAST, 2012, p. i)." The proposed solution was the design of public policies to "increase the number of students who receive undergraduate STEM degrees by about $34 \%$ annually over current rates (p. i)."

In this line of research, it is often implicit the assumption that more STEM graduates would lead to more innovation. In this paper, however, we intend to take a step back and study what is the effect of inducing more students to enroll in university-level STEM majors on the individual probability of producing innovation. Recent empirical research has documented that inventors are more educated than the average individual, especially in STEM fields (Giuri et al., 2007; Jung and Ejermo, 2014; Aghion et al., 2017; Bell et al., 2018; Akcigit, Grigsby and Nicholas, 2017). Establishing a causal effect between education and innovative activities, however, is challenging. Individuals who are inherently more inventive

might choose to invest more in education. Moreover, there are multiple channels through which education might affect innovation. In addition to increasing inventive skills, in fact, education might indirectly affect innovative outcomes through students' occupational choices. Shedding light on these mechanisms can highlight positive externalities of education that are not fully captured by private monetary returns and can help design interventions to spur 
economic growth and productivity.

The main idea behind this paper is to exploit an education reform that led to an abrupt increase in the supply of STEM graduates in post-WWII Italy. Before the reform, the Italian high school system was very restrictive in the post-graduation choices offered to its students. Until 1960, only students who graduated from university-prep high schools (hereafter, academic students) could enroll in university STEM majors. Students enrolled in any other type of high school, 69 percent of the student population, were prevented from enrolling in STEM majors. In particular, students in technical high schools for industrysector professionals (hereafter, industrial students) received a practical training in many STEM disciplines, but could not further their scientific education at the university level. In 1961, an important reform of the education system allowed industrial students to enroll in university STEM majors for the first time. ${ }^{1}$ This policy led to a sharp increase in the number of students choosing a university-level STEM education. The number of STEM freshmen rose from 12,222 students in 1960 to 38,627 students in 1968, a 216 percent increase in only 8 years.

Our identification strategy exploits the fact that the change in enrollment requirements increased the probability of receiving a university STEM degree only among the industrial students who completed high school after 1961, but not among older industrial students or students from different high schools. We therefore compare variations in innovative activities between cohorts of industrial and academic students before and after the reform.

We leverage three types of administrative data on the population of 46,473 students who completed high school in Milan, the economic and innovative capital of Italy, between 1958 and 1973: historical education data, which Bianchi (2019) collected directly from the archives of high schools and universities; employment histories provided by the Social Security Institute; patents issued by the Italian Patent Office (IPO) between 1968 and 2010, and all international patents included in the European Patent Office's PATSTAT database. We match the inventors listed in the patent data to school and employment records. This process allows us to identify 869 individuals who produced at least one patent.

We find three key results. First, scientific higher education had a direct impact on the type of innovation produced. Industrial students who had earned a STEM degree became more likely to patent in the fields of chemistry, medicine, and IT, and less likely to patent in mechanics and industrial processes. Second, most industrial students who had earned a STEM degree became more likely to patent. Compared with similar industrial students who completed high school before the reform, they found employment in similar economic sectors (privately owned manufacturing firms), but became more likely to occupy higher-ranked

\footnotetext{
1 This policy did not change any other restriction in the access to university majors (Figure A1).
} 
positions and to be involved in innovative processes. Third, access to scientific education changed sorting into occupations. Compared with an industrial high school diploma, a university STEM degree led to more job opportunities than just technical positions within manufacturing firms. Some industrial students with high precollegiate ability used their STEM degree to access self-employed professions and public jobs. These occupations were not accessible with only a high school diploma and did not focus on the production of patents. Consequently, the innovative propensity of these higher-achieving industrial students decreased.

Our results corroborate the existing evidence of a positive correlation between education and innovation. Higher human-capital accumulation has the potential to spur and shape innovative outcomes. Our findings, however, complement these results by linking innovation outcomes to several changes in the external and internal labor markets. Our analysis reveals that higher education has a complex effect on innovation, because it can change selection into different occupations. If non-STEM sectors value scientific skills, an increase in scientific education can push some marginal students towards occupations that do not focus on innovation.

In other words, studying the relationship between education and innovation cannot prescind from analyzing the demand for innovation and innovative talent in the local labor markets. Increasing the number of STEM graduates might have different consequences on individual patenting activity and occupational sorting depending on whether the market for innovation is expanding or contracting. When the market for ideas is fixed, for example, Borjas and Doran (2012) show that a large increase in the supply of mathematical talent leads to substantial displacement of incumbent workers and changes in the direction of academic research. When increases in market size are able to absorb increases in supply of STEM talent, empirical studies do not find substantial negative effects on the individual production of innovation (Moser, Voena and Waldinger, 2014; Peri, Shih and Sparber, 2015)

In light of these considerations, how should we interpret our findings? Our results describe a labor market that was able to accommodate in large part the entry of new STEM graduates. The probability of producing patents increased for most industrial students with a STEM degree. The fact that some higher-achieving industrial students switched to non-innovative occupations shows that the existence of a healthy demand for STEM talent even in sectors that did not traditionally produce patents. Moreover, we find that industrial students earned more after receiving access to university-level STEM education. ${ }^{2}$

2 Bianchi (2019), however, discusses some costs incurred by incumbent STEM graduates and shows that the reform did not benefit all workers in the economy. 
This paper contributes to the literature on the returns to education. Previous research has highlighted that education leads to higher wages (Card, 1999, 2001; Meghir and Rivkin, 2011 for a review of this rich line of research); better health (Lleras-Muney, 2005; Silles, 2009; Cutler and Lleras-Muney, 2010; de Walque, 2010; Webbink, Martin and Visscher, 2010; Eide and Showalter, 2011); lower probability of incarceration and arrest (Lochner, 2004; Lochner and Moretti, 2004; Buonanno and Leonida, 2009; Cook and Kang, 2016); higher social capital (Dee, 2004; Milligan, Moretti and Oreopoulos, 2004; Wantchekon, Klasnja and Novta, 2015); and other non-monetary benefits (Grossman, 2006). This paper is one of the first to document how completing a STEM degree, instead of a technical high school diploma, affects innovation. Recent studies exploit the establishment of new universities to measure their effects on economic growth (Cantoni and Yuchtman, 2014) and innovation production (Toivanen and Väänänen, 2016; Andrews, 2019). This paper complements their analysis by showing the existence of heterogeneous effects between levels of pre-collegiate achievement, by relating changes in innovation propensity to sorting into different occupations, and by documenting effects on the fields of invention.

Finally, this paper is related to the literature that analyzes the career outcomes of innovators. Murphy, Shleifer and Vishny (1991) and Baumol (1990) study how the allocation of innovative talent across sectors affects economic growth. Philippon (2010) and Lockwood, Nathanson and Weyl (2017) investigate how the tax code could reflect the different degree of innovation between sectors. Shu (2016) describes how STEM students at MIT are selected into financial and scientific careers. This paper complements Shu (2016)'s results by exploiting a discontinuity in the supply of STEM talent, instead of in the demand for STEM skills,.

The rest of the paper is organized as follows: Section 2 describes the change in enrollment requirements in Italian STEM majors. Section 3 describes the data. Section 4 outlines the identification strategy, and Section 5 documents the effects on the fields of invention. Section 6 shows the effects on the likelihood of becoming an inventor. Section 7 investigates changes in occupation, and Section 8 concludes.

\section{The Reform of Admissions into University STEM Majors}

In Italy, there are three main types of high schools: academic, technical, and professional. Academic schools provide a theoretical education in the humanities and the sciences. Technical schools primarily teach applied disciplines related to one field of study and are categorized into different tracks, such as industry, commerce, and education. Students in the industrial track, for example, study applied STEM disciplines, while students in the commercial track 
study accounting and languages. Professional schools focus on short-term practical training for one specific occupation.

Until 1960, this three-tier high school system heavily influenced admissions into Italian universities. At the top, graduates of academic schools could choose any university major. In the middle, graduates of technical schools could enroll only in business economics, statistics, and a few other minor programs. Within this group, students in the industrial track were prevented from continuing their STEM studies at the postsecondary level and usually chose not to enroll in the university. At the bottom, graduates of professional schools could not enroll in any university major.

As the Italian industrial sector expanded in the post-WWII period, demand for highly skilled STEM workers increased significantly (Figure A2). Growth in university STEM degrees, however, was constrained by the fact that only students of academic schools - amounting to 30.9 percent of all high school graduates in 1960 - could enroll in university STEM majors. The first panel of Figure A3 shows the number of first-year students enrolled as STEM majors in all Italian universities, computed as the share of all high school graduates. In Italy, between 1958 and 1960, the enrollment share in STEM majors was constant at 11 percent.

To increase the amount of STEM skills in the economy, a 1961 reform known as "legge 685/61" allowed industrial students to enroll in university STEM majors for the first time. ${ }^{3}$ The affected majors were engineering, mathematics, physics, natural sciences, biology, geology, and chemistry. Between 1961 and 1964, industrial students competed for a restricted number of available slots and were selected with an exam. Starting in 1965, industrial students were fully equated to academic students and stopped facing an enrollment cap. In 1969, a reform known as "legge Codignola" allowed all students to modify the previously rigid university curricula by choosing a higher number of elective courses. ${ }^{4}$

The 1961 reform was associated with a substantial enrollment increase in STEM majors. The enrollment share in university STEM majors increased from 11.1 percent in 1960 to 12.9 percent in 1964 (panel A, Figure A3; ISTAT data). When the remaining restrictions for industrial students were lifted in 1965, the enrollment share in university STEM majors increased to 18.6 percent. This large increase persisted at least until 1973. The second panel of Figure A3 shows the number of first-year industrial students enrolled as STEM majors, again computed as the share of all high school graduates. The enrollment share in STEM

${ }^{3}$ Bianchi (2019) describes in greater details the effects of this reform on the accumulation of human capital.

4 The same "legge Codignola" granted all high school graduates access to any university major, regardless of the type of high school diploma. This part of the reform did not have any significant effect on the education choices of industrial students, as many of them kept enrolling in STEM programs. 
majors of industrial students grew from 1.7 percent in 1963 to 2 percent in 1964. In 1965, it increased dramatically to 6.8 percent and did not decrease through 1973.

\section{Data}

We analyze the effects of university STEM education on innovation by combining different types of administrative data on students who completed high school in Milan between 1958 and 1973. Milan provides an interesting setting for a study on innovative activities, due to its high propensity to innovation. According to the universe of patents issued by the Italian Patent Office between 1968 and 2010, 12.7 percent of patents were granted to an assignee located in Milan, despite the fact that Milan hosts only 2.1 percent of the Italian population (2011 Census).

\subsection{Education Data}

Bianchi (2019) collected and digitized the high school registers of 46,473 students who received an academic or technical diploma in Milan between 1958 and 1973. In addition to key identifying variables such as full name, birthdate, and birthplace, the registers contain information about performance on the high school exit exam (maturità). We standardize the high school grades by school and cohort and use them as a measure of pre-collegiate achievement. Moreover, we can compute the average grade of each student's closest peers, because each cohort was divided in small classes of 20-30 students attending lectures together. We use the classmates' average score as a measure of pre-collegiate peer effects. From the registers, we also identify "home-schooled" students who graduated from the school without attending the regular school year. These students were either educated at home or enrolled in private schools not allowed to administer the final exam.

Bianchi (2019) also collected and digitized student records kept by three universities in Milan: the Polytechnic University of Milan, the University of Milan, and the private Catholic University of the Sacred Heart. ${ }^{5}$ Collecting data exclusively from universities in Milan does not lead to a biased sample, because almost all students from Milan chose a local university: 94.1 percent in 1956 and 93.5 percent in 1967, according to the Italian Bureau of Statistics (ISTAT). For each student, we know the major chosen, year of enrollment, grade received in each university course, and final outcome (graduation, transfer, or dropout).

\footnotetext{
${ }^{5}$ Our sample does not include data from the private Bocconi University. Bocconi University is not relevant for the analysis, because it offered only a business economics major (accessible to technical students before 1961), charged high tuition fees, and admitted only a limited number of students each year.
} 


\subsection{Occupation Data}

Out of 46,473 students, 41,851 (90 percent) had a record in the database of the Italian Social Security Institute (INPS), a government agency that administers pensions and other forms of benefit mainly to employees in the private sector. INPS maintains an employer-employee panel database on all Italian workers, including self-employed and public employees. The information available for workers other than private employees, however, is limited to the pension fund to which they were contributing in a given year. Because the pension funds are tied to different jobs, we can categorize all workers in the sample into 40 occupations (Table A1). It is worth noting that in the Italian system there is a 1-to-1 correspondence between jobs and public pension funds: after choosing an occupation, workers cannot pick among different pension funds.

Most workers are employees in the private sector (64.4 percent), while 5.9 percent are public employees. The rest of the sample is represented by self-employed professionals, entrepreneurs, and other employees of private or public companies with special pension benefits (for example, postal service employees).

For employees in the private sector, we have additional information on the industry, position within the firm (apprentice, low/high blue collar, low/high white collar, or manager), and in some cases compensation.

\subsection{Patent Data}

We measure the innovative activity of individuals in the sample with data on the patents issued by the Italian Patent Office (IPO) between 1968 and 2010, and on the international patents included in the European Patent Office's PATSTAT database. The data distinguish between the assignees of a patent (the firms or individuals owning the intellectual property rights over the patented invention) and the inventors (the individuals who contributed to its development). This feature allows us to capture innovative activity even when the individual develops a patent as an employee or consultant without retaining any property right.

We matched the list of high school graduates to the list of inventors in different stages. Initially, we used the full name of the individuals to find 43,246 possible patent-individual matches. This first step ruled out the vast majority of irrelevant patents, but led to a large number of false positives. To improve the matching process, we employed three subsequent refinements. First, we exploited the fact that 7,796 matched patent-individual combinations issued after 1989 contained the tax code, which is a unique individual identifier for tax purposes. For these observations, we used the students' tax codes to find 496 correct and 7,300 incorrect matches. Second, we used the social security data to verify 
whether the employer of the alleged inventor matched the patent assignee in the year of the patent application. Thanks to the work histories provided by INPS, we were able to verify 2,662 matches as correct and 27,642 as incorrect. Third, we hired several contractors to search additional information on the matched inventors - such as birthdate, birthplace, and education - on LinkedIn or company websites. To improve precision, we sent each entry (a patent-inventor combination) to multiple contractors and personally checked all the data found online. Out of 880 patent-individual combinations for which we were able to find additional information, we were able to verify 663 of them as correct and 217 as incorrect. Out of the initial 43,246 matched patent-inventor combinations, we verified 38,980 entries and found 3,821 correct matches. In the main analysis, we dropped the 4,266 unverified patents from the sample, although the main results are robust to their inclusion (Appendix F).

\subsection{Characteristics of Inventors}

Out of 46,473 students, 869 inventors (1.9 percent of the sample) developed a total of 3,821 patents (Table 1). On average, one inventor is linked to four patents, but the distribution is heavily skewed to the right (median 2; 99th percentile 31). Relative to the rest of the sample, inventors are 24 percentage points more likely to be male and 0.9 years older. In addition, 64 percent of inventors received an industrial diploma, compared with 35 percent of non-inventors. As expected, inventors are positively selected in terms of academic abilities: they received a high school grade 0.26 standard deviations higher than the mean. Compared with the rest of the sample, inventors were more likely to attend university studies, especially in a STEM program, and were more likely to graduate. The retention rate in STEM majors is 80 percent for inventors and 65 percent for the rest of the sample. In the labor market, 94 percent of inventors were employees in the private sector, compared with only 88.5 percent of non-inventors. Outside of the private sector, inventors were more prominent in researchoriented jobs, such as university professors and academic researchers (2.4 percent versus 1.2 percent among non-inventors). Within the private sector, inventors were more likely to work in manufacturing (84 percent versus 52 percent) and in R\&D (2.3 percent versus 0.9 percent). In addition, inventors were more likely to reach managerial positions. The share of managers is 56 percent among inventors, but only 29 percent among non-inventors. 


\section{Identification}

\subsection{All Industrial and Academic Students}

We compare the innovative outcomes of industrial and academic students. Students with an academic diploma were not directly affected by the change in university access, since they could freely enroll in university STEM majors before and after 1961. ${ }^{6}$ As a result, the policy significantly increased university STEM education only among industrial students who completed high school after 1961. Relative to academic students, the graduation rate of industrial students in STEM majors increased by 4.0 percentage points between 1961 and 1964, by 17.2 percentage points between 1965 and 1968, and by 16.7 percentage points between 1969 and 1973 (Table A2, panel A, column 1). ${ }^{7}$ All increases are statistically and economically significant.

The differential increase in university STEM education occurred only among cohorts who finished high school after 1961, even though the reform granted every cohort of industrial students access to STEM degrees. The coefficients of the interaction between pre-reform cohort fixed effects, 1959 and 1960, and Industrial, a dummy variable equal to 1 for industrial students, are not statistically significant (Table A2, panel A, column 2). Similarly, the coefficient of the interaction between a pre-reform linear trend and the variable Industrial is close to zero and not statistically significant (Table A2, panel A, column 3). The differential change in university STEM education results from two separate effects: a large cross-cohort increase among industrial students, as well as a decrease among academic students (Figure 1, panel A). This decreasing pattern suggests that some academic students might have decided to avoid STEM majors after 1961, in favor of other programs still not accessible to industrial students (Bianchi, 2019). In Section 4.2, we propose an alternative specification that addresses this fact.

In the empirical analysis, we estimate the regression

$$
\text { Invention }_{i t}=\alpha+\beta \text { Industrial }_{i}+\gamma_{t}+\sum_{t} \delta_{t}\left[\text { Industrial }_{i} \times \text { Post }_{t}\right]+\zeta X_{i t}+u_{i t}
$$

\footnotetext{
${ }^{6}$ By granting access to university STEM majors, the 1961 reform significantly increased the option value associated with an industrial diploma. As a result, the selection of students into different types of high schools might have changed. In Section 6.5, we perform several robustness checks to address this concern.

${ }^{7}$ Here and in the rest of the paper, the phrase "between 1961 and 1964" refers to the cohorts who completed high school between 1961 and 1964, "between 1965 and 1968" to the cohorts who completed high school between 1965 and 1968, and "between 1969 and 1973" to the cohorts who completed high school between 1969 and 1973.
} 
on a sample that comprises industrial and academic students. The unit of observation is a student $i$, who completed high school in year $t$. The dependent variable Invention ${ }_{i t}$ is a measure of innovative activity, such as a dummy variable equal to 1 for the individuals who developed at least one patent between 1968 and 2010, the number of developed patents, or the number of technological fields in which an individual invented. Post $t$ is a series of dummy variables that identify the cohorts who completed high school after the first policy implementation: Post 1961 is 1 for students who completed high school between 1961 and 1964, Post 1965 is 1 for students who completed high school between 1965 and 1968, and Post 1969 is 1 for students who completed high school between 1969 and 1973 . Industrial ${ }_{i}$ is a dummy that identifies industrial students. $\gamma_{t}$ are cohort fixed effects, while $X_{i t}$ are student characteristics, such as gender, province of birth fixed effects, fixed effects for each high school in the data, the average standardized score of the closest peers in high school, a dummy for home-schooled students, and a dummy for students who graduated high school on time at 19. Standard errors are clustered at the high school and cohort level.

We explore the existence of a common pre-reform trend in innovative activity between industrial and academic students by estimating equation (1) on the cohorts who completed high school before 1961. We replace Post $_{t}$ with either a linear trend or cohort fixed effects. The results indicate the existence of parallel pre-reform linear and nonlinear trends between industrial and academic students in both the probability of becoming an inventor and the number of developed patents (Table 2, panel A, columns 1 to 4). The same finding holds if we estimate pre-reform trends at a higher level of aggregation. We can, for example, create a new dataset in which each observation represents a different combination of year of high school graduation, high school class - defined as a small group of 20-30 students attending lectures together - and quartile of pre-collegiate achievement. This sample still shows the existence of parallel pre-reform trends between industrial and academic schools (Table 2, panel B, columns 1 to 4). Finally, we can aggregate the observations at the level of year of high school graduation, high school, and quartile of pre-collegiate achievement. This dataset confirms the hypothesis of common pre-reform trends (Table 2, panel C, columns 1 to 4).

\subsection{Matched Industrial and Academic Students}

In addition to the previous intent-to-treat estimation, we intend to isolate the effect of university STEM education on the industrial students who actually received a STEM degree after 1961. The challenge in performing this analysis is that we do not directly observe the industrial students in the pre-reform cohorts who would have completed a STEM degree, had they graduated high school after 1961. To create a balanced pre-reform sample, we match 
post-reform industrial students with a STEM degree to pre-reform industrial students, using nearest-neighbor propensity score matching. ${ }^{8}$ We first limit the sample to male students, because female participation into high school increased over time. We then compute the propensity scores using the available pre-collegiate characteristics, such as high school fixed effects, the score in the exit exam, the average score of the high school's peers, and a dummy for home-schooled students. We repeat this process for each quartile of pre-collegiate ability and pre-reform cohorts.

The resulting sample of 1,719 industrial students has balanced characteristics before and after 1961 (Table A3, panel A). All the observable characteristics used in the matching process do not statistically differ between post-reform students with a STEM degree and matched pre-reform industrial students. Among higher-achieving students, for example, the average high school score is equal to 1.68 standard deviations among pre-reform matched students and to 1.75 standard deviations among post-reform students with a STEM degree. The difference is small and not statistically significant. It is also interesting to note that a variable not used to compute the propensity scores - a dummy that identifies students completing high school at the standard age of 19 -is balanced between the two groups.

As a control group, we use academic students with a STEM degree. As a direct response to the entry of industrial students in STEM majors, however, some academic students might have turned to different university programs after 1961, changing the average characteristics of STEM students with an academic diploma. To address this concern, we select only prereform academic students who would have been more likely to receive a STEM degree, had they completed high school after 1961. Using the same nearest-neighbor propensity score algorithm, we match post-reform academic students with a STEM degree to pre-reform academic students with a STEM degree. The result is a sample of 3,001 academic students with a STEM degree, whose characteristics are balanced across cohorts (Table A3, panel B).

In the empirical analysis, we then re-estimate regression (1) on a sample that includes only matched industrial and academic students. The data indicate that the innovative activity of these two groups of students followed a similar pre-reform path (Table 2, , columns 5 to 8).

\section{$5 \quad$ Effects on the Type of Innovation}

In this section, we study whether a university STEM education had a direct impact on the innovative activities of industrial students by leveraging information on the field of invention from patent applications. Each granted patent, in fact, is assigned to a class that identifies

\footnotetext{
8 To estimate the effect of the policy on treated students, we prefer matching over other techniques, like instrumental variable estimation, because we can directly control for changes in observables.
} 
the technological area to which the invention belongs. Following the International Patent Classification (IPC), we divide the matched patents into 10 major fields: human necessities, medicine (class A61), industrial operations, chemistry, textiles, constructions, mechanical engineering, physics, electricity, and IT (classes H03, H04, G06, and G11).

\subsection{Graphical Evidence}

Industrial and academic students produced patents in different technological areas before 1961. The distribution of inventors in pre-reform cohorts across different technological areas shows that 24.7 percent of inventors with an academic diploma patented in the field of chemistry, compared with only 13.1 percent of inventors with an industrial diploma (Figure 2, panel A). Similarly, academic students with STEM degrees were more likely to patent in medicine (9.3 percent versus 7.1 percent); textiles (3.1 percent versus 1.2 percent); constructions (6.2 percent versus 2.4 percent); and IT (4.1 percent versus 3.6 percent). ${ }^{9}$

The industrial students who pursued a STEM degree after 1961 began patenting more in the same fields in which academic students with a STEM degree had been more prevalent before 1961 (Figure 2, panel B). The share of inventors with an industrial diploma and a STEM degree increased by 7.1 percentage points in chemistry and by 8.2 percentage points in medicine. In industrial operations - in which industrial students were more likely to patent before the reform - the share of industrial inventors with a STEM degree decreased by 5.1 percentage points. The industrial students who did not receive a STEM degree after 1961 exhibit a different pattern (Figure 2, panel C). Their likelihood to patent did not increase in chemistry and medicine, but increased by 1.1 percentage points in industrial operations. This last graph suggests that more patenting in fields such as chemistry and medicine by industrial students who pursued a STEM degree after 1961 does not reflect secular changes in technology, but is likely driven by access to university STEM education. ${ }^{10}$

\subsection{Regression Analysis}

To further analyze changes in the type of innovation, we estimate equation (1) on the sample of individuals who patented at least once. In these regressions, the dependent

\footnotetext{
${ }^{9}$ In spite of the small number of observations, the preexisting differences in human necessities, chemistry, and constructions are statistically different from zero (Table A4, panel A).

${ }^{10}$ Regressions further confirm these findings. Post-reform changes for industrial students with a STEM degree are large in magnitude and directed towards fields in which academic students were more likely to patent before the policy (Table A4, panel B). Post-reform changes for industrial students without a STEM degree are small in magnitude, not statistically significant, and directed towards other fields (Table A4, panel C).
} 
variable STEM field $\mathrm{S}_{i t}$ is equal to 1 if an inventor patented at least once in a STEM-oriented technological area. We define STEM-oriented fields as those in which academic students with a STEM degree were more likely to patent before 1961. In the matched sample, the likelihood of industrial students to patent in medicine, chemistry, or IT increased by 69.9 additional percentage points between 1965 and 1968, and by 46.7 additional percentage points between 1969 and 1973, compared with matched academic students with a STEM degree (Table 3, panel B, column 1). These coefficients indicate that innovative activities in these areas increased between 164 and 245 percent, relative to the pre-reform baseline. These findings are robust if we use the full unmatched sample (Table 3, panel A), a less-restrictive definition of STEM fields (Table 3, column 2), or if we divide the sample between higherand lower-achieving students (Table 3, columns 3 to 6 ).

The previous findings could confound a shift in patenting towards STEM fields with an overall increase in inventiveness. The same patenting increase observed in STEM fields, in fact, could have happened in other technological areas. We test this hypothesis by making a small modification to the previous analysis. In these new regressions, the dependent variable is the share of patents produced in STEM fields. These specifications also include the total number of patents produced by each inventor as an additional control. The results confirm that access to university-level STEM education caused a shift in patenting towards more traditional STEM fields among industrial students, even after keeping fixed the overall number of patents produced. In the matched sample, the share of patents produced by industrial students in STEM fields increased by 49.9 percentage points between 1965 and 1968, and by 28.3 percentage points between 1969 and 1973 (Table A5, panel B, column 1). The coefficients imply that the propensity to patent in STEM fields more than doubled relative to the pre-reform baseline. ${ }^{11}$

Alternatively, we can create a dataset in which a unit of observation is an inventor-field combination (instead of just an inventor). The dependent variable Patenting ${ }_{i t c}$ is equal to 1 if an inventor $i$, who completed high school in year $t$, patented at least once in class c. We regress this dummy on a triple interaction of Industrial $_{i} \times$ Post $_{t} \times \mathrm{STEM} \mathrm{field}_{c}$, as well as the three variables not interacted, all possible double interactions, and other demographic controls. These specifications allow us to control for class-specific fixed effects and trends. A positive coefficient for the triple interaction would suggest that the industrial students became more likely to patent in STEM fields after the reform, compared with other technological areas and academic students. In the matched sample, the likelihood of

\footnotetext{
${ }^{11}$ These findings are qualitatively similar for alternative definitions of STEM fields (Table A5, panel B, column 2), for students with different levels of precollegiate ability (Table A5, panel B, columns 3 to 6), and for the full sample that includes unmatched students (Table A5, panel A).
} 
industrial students to patent in STEM fields increased by 22 percentage points between 1961 and 1964, by 26.8 percentage points between 1965 and 1968, and by 14 percentage points between 1969 and 1973, relative to a pre-reform propensity to innovate of 19 percent (Table A6, panel B, column 1).

\section{$6 \quad$ Effects on Innovation Propensity}

This section describes the effects of increased university STEM education on the probability of producing patents. The analysis reveals the existence of heterogeneous effects on innovation between levels of pre-collegiate achievement.

\subsection{Theoretical Framework}

In this section, we introduce a simple theoretical framework to assess how access to STEM majors might have affected the innovation propensity of industrial students. We assume the existence of two sectors: a STEM sector, in which individuals have the option to innovate, and a non-STEM sector, which does not produce any innovation. Individuals, therefore, have three occupational choices: working in a STEM field and inventing, working in a STEM field without inventing, and working in a non-STEM field.

The utility of an industrial student in STEM fields (without individual subscripts) is

$$
u_{S}=d \cdot w_{d}+(1-d) \cdot w_{h s}+i \cdot g(a, d)+\varepsilon_{S},
$$

where $d$ is equal to 1 for individuals with a university STEM degree, and is 0 for individuals with an industrial high school diploma. The wages $w_{d}$ and $w_{h s}$ capture the different marginal returns of university-level and high school-level STEM skills. The function $g(a, d)$ captures the personal net gains from innovation and depends positively on natural ability $(a)$ and possibly on human capital $(d)$. The dummy variable $i$ is equal to 1 for inventors, and 0 otherwise. If education has a positive effect on innovation, the function $g()$ is increasing in $d: g(a, 1)>g(a, 0)$, keeping $a$ fixed.

The production function in the non-STEM sector utilizes university-level STEM human capital, but does not employ workers with a more narrowly applicable industrial high school diploma. The utility of an industrial student in non-STEM fields is

$$
\begin{cases}u_{N}=w_{n}-c(a)+\varepsilon_{N} & \text { if } d=1 \\ u_{N}=0 & \text { if } d=0\end{cases}
$$


where $c(a)$ is a cost that STEM graduates incur by finding a job in a non-STEM field. This cost function $c()$, which decreases with natural ability, might capture the challenges of working in an industry without any related academic preparation. STEM graduates who find employment in finance, for example, might have to learn post-graduation how financial markets work. The function $c()$ might also describe the existence of barriers to entry into non-innovative occupations, such as strict licensing regulations. Because the errors $\varepsilon_{S}$ and $\varepsilon_{N}$ follow a univariate extreme value distribution, we can write the probability of each occupational choice as a multinomial logit.

In this setting, acquiring a university STEM degree has an ambiguous effect on the probability of inventing. ${ }^{12}$ Moving from an industrial high school diploma to a university STEM degree, in fact, has two opposite effects on the probability of producing innovation. First, if function $g()$ is increasing in $d$, a university STEM education increases the net gains of innovation and induces more people to become inventors. This is the direct effect of increased human capital on innovative activities. Second, a university STEM education might push some individuals into the non-STEM sector, which was not a viable option with just an industrial diploma.

Moreover, the selection of industrial students into non-STEM majors also depends on two counteracting forces. On the one hand, higher-ability students incur a lower cost of adapting to an unfamiliar economic sector, because $c()$ is decreasing in $a$. On the other hand, they gain more from innovative activities in the STEM sector, because $g()$ is increasing in $a$. If the former effect prevails, the most able industrial students would move towards the non-STEM sector after receiving a university STEM degree.

Although fairly stylized, this framework describes well two features of the Italian labor market for industrial students at the time of the education policy. First, there were jobs ("periti industriali") that specifically required an industrial diploma and focused on patenting (in the framework, "STEM sector"). Before the reform, most industrial students joined positions in the "STEM sector" because they had the right skillset and could avoid competition for jobs from other types of students. ${ }^{13}$ Similarly, many occupations were accessible only with a university-level degree, in some cases a STEM degree, but did not focus on patenting ("non-STEM sector"). ${ }^{14}$ Given the characteristics of the Italian labor

\footnotetext{
${ }^{12}$ Appendix $\mathrm{C}$ contains more details about these predictions.

${ }^{13}$ In other European labor markets in which technical high schools are either not present or popular, these jobs require a university-level degree (often an engineering degree). Even in Italy, recent law changes (law 89/2016) have raised the education thresholds to enter these positions, but only for new graduates.

${ }^{14}$ Self-employed engineers, for example, must hold a university-level STEM degree, often earn more than industrial workers, and do not develop patents as part of their normal tasks. Similarly, higher-ranked public positions were not accessible with just a high school diploma, making a career in the public sector much more attractive with a university education.
} 
market, receiving a university-level degree might have induced some industrial students to avoid the STEM-related jobs traditionally reserved for them (with high focus on innovation) in favor of other desirable occupations that were reserved for university graduates (possibly with lower focus on patenting). Second, it is plausible to assume that this move away from the "STEM sector" might have been concentrated among higher-achieving students. Many occupations in the non-STEM sector (university degree required, but low focus on patenting) had significant barriers to entry in the form of national examinations. In addition, many "non-STEM" occupations were self-employed positions. The high variance of returns in these jobs (relative to employed positions) might have deterred lower-achieving students.

\subsection{Intent-to-Treat Analysis: All Industrial vs. Academic Students}

We first estimate equation (1) using as the dependent variable an indicator for students who patented at least once between 1968 and 2010. ${ }^{15}$ The estimating sample includes all industrial and academic students. There is no evidence of a differential change in the propensity to innovate between industrial and academic students who completed high school between 1961 and 1968 (Table 4, panel A, column 1). Among the cohorts who completed high school between 1969 and 1973, the propensity of industrial students to innovate decreased by 1.1 percentage points. The effect of increased STEM education, however, varied extensively across students with different pre-collegiate achievement.

The likelihood of becoming an inventor decreased for industrial students who scored in the top quartile of the high school exit exam. Compared with top academic students, the propensity of top industrial students to innovate decreased by 0.02 percentage points between 1961 and 1964, by 3.2 percentage points between 1965 and 1968, and by 4.0 percentage points between 1969 and 1973. The last two coefficients are statistically significant at the 5 and 1 percent level, respectively. Considering that 7.4 percent of top industrial students became inventors before 1961, these effects imply that the propensity of top industrial students to innovate decreased by 43 to 54 percent. These results are robust to the inclusion of controls for pre-reform trends in the inventiveness of top industrial students (Table 4, panel A, column 4). Panel A of Figure 3 shows separately the cross-cohort change in the innovation propensity of top industrial and academic students. While the propensity of top academic students to innovate stayed fixed, the probability of becoming an inventor of top industrial students decreased significantly after $1965 .{ }^{16}$

\footnotetext{
${ }^{15}$ Additional outcomes (number of patents and number of technological fields) and specifications in Appendix D.

${ }^{16}$ The lack of a significant decline between 1961 and 1964 could be due to the fact that these cohorts were still facing enrollment caps into STEM majors. In Section E of the appendix, we explore a different hypothesis.
} 
Among lower-achieving industrial students, the propensity to innovate increased after the reform. Their probability of becoming an inventor increased by 1.2 percentage points between 1965 and 1968, and did not change significantly among other post-reform cohorts (Table 4, panel A, columns 5 and 6$) \cdot{ }^{17}$

\subsection{Effect on the Industrial Students with a University STEM Degree}

We then isolate the effect of increased access into STEM majors on the industrial students who pursued a STEM degree after 1961 by matching pre-reform industrial students to postreform industrial students with a STEM degree. In order to have a balanced control group, we also matched pre-reform academic students with a STEM degree to post-reform academic students with a STEM degree.

This analysis confirms that the effects of scientific education on innovation are heterogeneous across levels of pre-collegiate achievement. Among industrial students scoring in the top quartile of the high school exit exam and receiving a STEM degree, the probability of becoming an inventor decreased by 0.4 percentage points between 1961 and 1964, by 6.8 percentage points between 1965 and 1968, and by 6.3 percentage points between 1969 and 1973 (Table 4, panel B, column 3). These findings suggest that the innovation propensity decreased by 53 to 58 percent after 1965, relative to the pre-reform baseline.

Among industrial students scoring in the bottom three quartiles of the high school exit exam and receiving a STEM degree, the probability of becoming an inventor increased by 6.6 percentage points between 1961 and 1964, by 7.9 percentage points between 1965 and 1968, and by 5.3 percentage points between 1969 and 1973 (Table 4, panel B, column 5). All three coefficients are statistically different from zero and robust to the inclusion of a linear pre-reform trend (Table 4, panel B, column 6). This finding does not originate from the fact that the matching process selected fewer inventors among the pre-reform cohorts. The share of inventors before 1961, in fact, is equal to 5.6 percent in the matched sample, but only to 3.5 percent in the full sample.

Section 5 showed that industrial students, conditional on being inventors, shifted towards patenting in STEM fields after the reform (intensive margin). Was there also an increased entry of inventors in STEM fields (extensive margin)? We estimate equation 1 using as the dependent variable an indicator for students who patented in a STEM field (instead of

Data from university transcripts show that students selected different electives exams after 1965. Different exam choices might have affected human capital accumulation and, in turn, innovation outcomes.

${ }^{17}$ The results are robust if the sample is restricted to men (Table A7). Moreover, instrumental variable estimates of the effect of receiving a STEM degree on the probability of becoming an inventor confirm this heterogeneous pattern (Table A8). 
any field) at least once between 1968 and 2010. In the matched sample, the probability of industrial students to patent in a STEM field increased by 5.7 percentage points between 1961 and 1964, by 5.1 percentage points between 1965 and 1968, and by 2.7 percentage points between 1969 and 1973 (Table A9, panel B, column 1). ${ }^{18}$ There is not anymore an heterogeneous effect across different levels of precollegiate ability. The coefficients are positive for both students in the top quartile of the high school exit exam (Table A9, panel B, column 3) and for students in the bottom three quartiles (Table A9, panel B, column 5). These findings indicate that the negative effects on the baseline innovation propensity of top industrial students (Table 4, panel B, column 3) stem from individuals who would have patented in non-STEM fields without the reform.

Instead of relying on cross-sectional data, we can repeat the baseline analysis with a panel dataset. In this case, an observational unit is an individual $i$, who completed high school in year $t$, and is active in the labor market in the calendar year $y$. This specification allows us to control for calendar year fixed effects in innovative activity. We regress individual patenting outcomes observed in year $y$ on the usual set of differencein-differences variables (Industrial ${ }_{i} \times$ Post $_{t}$ ), all the controls in equation (1), and calendar year fixed effects. The yearly probability of patenting of lower-achieving industrial students increased by 2.6 percentage points between 1961 and 1964, by 1.2 percentage points between 1965 and 1968, and by 0.9 percentage points between 1969 and 1973 (Table A10, panel B, column 5). The yearly innovation propensity of higher-achieving students decreased between 0.6 and 0.8 percent, but the coefficients are not statistically different from zero (Table A10, panel B, column 3).

\subsection{Controlling for Patent Quality}

The patent count is an imperfect measure of innovation because patents can vary in their innovative content (Griliches, 1990). To control for patent quality, Trajtenberg (1990) suggests using the number of forward citations, because a common requirement in patent applications is to include references to previous related inventions. Citations, however, are not available in the Italian patent data. To address this issue, we matched the 46,473 individuals in our sample with inventors in the NBER US Patent Citation Data File (Hall, Jaffe and Trajtenberg, 2001), following the same procedure described in Section 3.3. Out of 869 total inventors in our sample, 301 patented at least once in the United States. We consider these 301 individuals as inventors of higher-quality (or higher-valuation) patents,

\footnotetext{
${ }^{18}$ The results are qualitatively similar for alternative definitions of STEM fields (Table A9, panel B, column 2), and for the full sample that includes unmatched students (Table A9, panel A).
} 
because patenting for an Italian inventor is more expensive in the United States than in Italy. ${ }^{19}$

We then repeat our analysis on the probability of developing at least one patent issued by the US Patent Office (Table A11). The intent-to-treat analysis (panels A) is consistent with the main findings in Table 4: the decrease in innovation propensity is larger among higher-achieving industrial students. If we focus on individuals who received a STEM degree after 1961 (panel B, the matched sample), the data reveal different effects for higher- and lower-achieving students. ${ }^{20}$

Among industrial students scoring in the top quartile of the pre-collegiate distribution and receiving a STEM degree after 1961, there is not a significant change in innovation propensity. This result suggests that the decrease observed using Italian patents is driven by individuals who would not have produced higher-quality inventions covered by US patents. This finding is robust to two different dependent variables: a dummy for inventors of US patents (Table A11, panel B, column 3), and the citation-weighted number of developed US patents (Table A11, panel B, column 4). Among lower-achieving industrial students with a STEM degree, however, there is a significant increase in innovation propensity. The probability of developing at least one US patent increased by 4.8 percentage points between 1961 and 1964, by 5.3 percentage points between 1965 and 1968, and by 3.7 percentage points between 1969 and 1973 (Table A11, panel B, column 5).

In addition to using citations and US patents to isolate higher quality inventions, we can use individual earnings to isolate inventors who might have gained the most from their innovative activity. Depalo and Di Addario (2014) use Italian data to show that inventors are able to partially appropriate the value of their inventions even when the resulting patent belongs to their employer. Moreover, they find that returns to patents peak the year before submission to the Patent Office. Following these results, we measure individual returns to patents as the work-related income change between period $t-3$ and $t-1$, where $t$ is the year in which a patent was submitted to the Patent Office. ${ }^{21}$ The average income growth between $t-3$ and $t-1$ is 11 percent (standard deviation 40 percent, 75 th percentile 18 percent). We

\footnotetext{
${ }^{19}$ Although the direct fees charged by the two patent offices are comparable (a minimum of $\$ 70$ in the United States and $€ 50$ in Italy), an Italian inventor who aspires to patent in the the United States will need a professional English translation of the patent documents and most likely the help of a local patent attorney.

${ }^{20}$ The fact that this pattern of results (no effect among higher-achieving students and large positive effects among lower-achieving students) is present only in the matched sample suggests that the matching process might be able to eliminate selection bias stemming from cross-cohort changes. In the unmatched sample, for example, a higher selectivity of academic students over time might lead to negative bias in the estimated effect of the policy among industrial students. The consequences of this bias might be larger when the outcome is rarer, such as in the case of higher-quality inventions.

${ }^{21}$ Due to limited income data, this analysis includes only inventors employed in the private sector.
} 
then define as high-quality inventions only those patents that are associated with an income increase above the mean. ${ }^{22}$ This process lowers the number of inventors from 869 to 337.

In the panel dataset, we then regress the production of high-quality patents of individual $i$ in calendar year $y$ on the difference-in-differences variables (Industrial ${ }_{i} \times$ Post $_{t}$ ), all the controls in equation (1), and calendar year fixed effects. The results confirm the findings obtained using US patents. In the matched sample, there is no evidence of a significant decrease in innovation propensity among higher-achieving students. The effect on the probability of producing patents with above-average returns is a precise zero (Table A12, panel B, column 3). The effect, instead, is positive and statistically significant among lower-achieving students. Among this subgroup, the probability of developing high-return patents increased by 0.99 percentage points between 1961 and 1964, by 0.61 percentage points between 1965 and 1968, and by 0.51 percentage points between 1969 and 1973 (Table A12, panel B, column 5). These coefficients indicate that innovation propensity increased more than 200 percent from a yearly patenting probability of 0.25 percent. This pattern is present even if we focus only on patents in more traditional STEM fields (Section 5; Table A12, columns 2, 4, and $6)$.

\subsection{Controlling for Entry into Industrial High Schools}

The reform might have changed selection into different high schools, drawing students who were interested in pursuing a university STEM degree into industrial schools. Here we present several tests that address this concern.

First, we estimate cross-cohort changes in innovative activity using only data from either academic students (Table A13, panel A) or commercial students (Table A13, panel B). In both cases, the analysis indicates that after 1961 the probability of becoming an inventor did not change between academic or commercial students with higher and lower pre-collegiate achievement. The coefficients of the interaction between post-reform cohort dummies and Top $_{i}$ are all close to zero and not statistically significant. ${ }^{23}$ These findings rule out the hypothesis that the most or least inventive students switched to industrial schools after the reforms, because the average probability of becoming an inventor did not change among students attending other high schools.

Second, we estimate equation (1) on a smaller sample of students who completed high school before 1966. These cohorts, in fact, enrolled in high school before the implementation

${ }^{22}$ Results are robust to using alternative definitions of high-quality inventions, such as patents associated with an income change above the 75 th percentile.

${ }^{23}$ The findings are robust to the choice of different dependent variables, such as the number of developed patents or the number of different areas of innovation (Table A13, columns 3 to 6). 
of the first policy (1961) and could not have easily transferred to other types of schools after 1961. ${ }^{24}$ Among high-achieving industrial students, the intent-to-treat analysis confirms that the decrease in innovation started before 1966. Compared with academic students, the probability of becoming an inventor among top industrial students decreased by 0.9 percentage points between 1961 and 1964, and by 4.8 percentage points in 1965 (Table A14, panel A, column 3). If we focus on the top industrial students who received a STEM degree, the data indicate that the probability of becoming an inventor decreased by 4.52 percentage points between 1961 and 1964, and by 4.7 percentage points in 1965 (Table A14, panel B, column 3). These coefficients, however, are not precisely estimated. Among industrial students who scored in the bottom three quartiles of pre-collegiate achievement, the increase in innovation propensity is statistically significant before 1966. In panel C, for example, the data indicate that lower-achieving industrial students with a STEM degree became more likely to innovate by 8.1 percentage points between 1961 and 1964, and by 14.7 percentage points in 1965, relative to pre-reform cohorts and academic students with a STEM degree (Table A14, panel B, column 8).

Third, we estimate equation (1) using weights that keep the average observable characteristics of the sample constant across pre- and post-reform cohorts (DiNardo, Fortin and Lemieux, 1996). These weighted OLS estimators confirm the existence of a decrease in innovation propensity among top industrial students. Compared with academic students, the probability of becoming an inventor of top industrial students decreased by 0.6 percentage points between 1961 and 1964, by 3.9 percentage points between 1965 and 1968, and by 4.3 percentage points between 1969 and 1973 (Table A14, panel A, column 4). Among industrial students scoring in the bottom three quartiles of pre-collegiate achievement, however, the share of inventors increased by 1.3 percentage points between 1965 and 1968 (Table A14, panel A, column 9). The coefficients are close to the baseline OLS estimates in Table 4.

Fourth, we modify the matching process described in Section 4.2. We match STEM graduates in the cohorts between 1961 and 1965 (who enrolled in high school without knowing about the policy) to both pre-1961 and post-1965 students. The results are very similar to the main findings on the matched sample. Among industrial students scoring in the top quartile of the high school exit exam and receiving a STEM degree, the probability of becoming an inventor decreased by 14.5 percentage points between 1965 and 1968, and by 16.6 percentage points between 1969 and 1973 (Table A14, panel B, column 5). Among industrial students scoring in the bottom three quartiles of the high school exit exam and receiving a STEM

\footnotetext{
${ }^{24}$ Strong anticipation effects were not likely, because the reform was swiftly implemented by a short-lived government. During this time period, the instability of coalition governments created uncertainty in the introduction of new policies. Between 1958 and 1970, 13 different governments retained power on average only 9.5 months.
} 
degree, the probability of becoming an inventor increased by 7.4 percentage points between 1965 and 1968 (Table A14, panel B, column 10).

Fifth, we use a representative survey of the Italian population (the Bank of Italy's Survey of Household and Income Wealth) to test whether paternal and maternal characteristics of students who enrolled in industrial school after 1961 changed systematically. Compared with industrial students, pre-reform academic students were more likely to have parents who had at least a high school diploma and were employed in higher-paying occupations. There is no evidence, however, that the parental characteristics of academic and industrial students became more homogenous after 1961 (Table A15). This finding suggests that the reform did not significantly change sorting of students across different types of Italian high schools. This result is consistent with the hypothesis that access to university majors is only one of many features that Italian families evaluate at the time of high school enrollment. Other characteristics (possibly perceived social stigma associated with technical schools) might have prevented most students interested in university-level STEM majors to abandon the idea of enrolling in an academic high school and instead join an industrial high school.

\section{Effects on Labor Market Outcomes}

Why did the propensity to innovate increase only among lower-achieving students after 1961 ? This section addresses this question by exploring how industrial students sorted into different occupations after 1961. Most lower-achieving industrial students with STEM degrees remained employees in the private sector, mainly in manufacturing and other industries with a high propensity to patent. In these sectors they became more likely to be employed as managers, who are more often listed as inventors in patent applications. Meanwhile, some higher-achieving industrial students with a STEM degree moved to occupations with higher earnings, but relatively low levels of innovation, such as self-employed engineers.

\subsection{The Relationship Between Occupations and Innovation}

We start our analysis by showing that there is a strong correlation between occupations and the probability of being an inventor. In a panel dataset in which an observational unit is an individual-year combination, we regress the innovative output of individual $i$ in year $y$ on occupational variables, the same demographic characteristics used in the previous analysis, and calendar year fixed effects. In these specifications, the coefficients of the occupational variables are large in magnitude and statistically different from zero (Table A16). Relative to employees in the private sector and keeping other individual features

fixed, the probability of patenting in a given year decreases by 0.08 percentage points 
among self-employed professionals, by 0.09 percentage points among public employees, by 0.13 percentage points among entrepreneurs and artisans, by 0.14 percentage points among law professionals (lawyers, notaries, chartered accountants), and by 0.16 percentage points among media professionals (entertainers and journalists). These coefficients suggest that the innovation propensity in these occupations is between 40 and 80 percent lower than the baseline probability of innovating in a given year ( 0.2 percent for employees in the private sector; Table A16, panel A, column 1). The correlations are largely unaffected even if the specifications control directly for education (Table A16, panel A, column 2). For example, after controlling for completed university-level education, the probability of producing patents is 0.12 percentage points lower for public employees than for private workers. $^{25}$ These results suggest that there is a strong connection between jobs and patenting. Any education reform that induces students to switch jobs might then have consequences on the individual probability of developing patents.

We then study how occupational sorting of industrial students with and without a STEM degree changed after 1961. Industrial students who completed a STEM degree after 1961 became more likely to choose self-employment or the public sector (Figure 4, panel A). ${ }^{26}$ Relative to the pre-reform cohorts, industrial students with a STEM degree became more likely to work as self-employed engineers (+4.3 percentage points); other self-employed professionals $(+3$ percentage points); public employees for the central government $(+2.6$ percentage points); or local governments $(+1.9$ percentage points). Instead, they became less likely to be employed in the private sector (-5.3 percentage points), or to work as artisans (-4.8 percentage points); entrepreneurs (-3.1 percentage points); and self-employed surveyors (-1.2 percentage points). These occupational shifts moved many industrial students with a STEM degree from jobs with a relatively high propensity to produce patents (for example, 1.6 percent of private employees developed at least one patent during their career) to less patentcentric jobs (for example, only 0.6 percent of self-employed engineers produced patents). ${ }^{27}$

Industrial students who did not receive a STEM degree after 1961 did not experience the same occupational shifts (Figure 4, panel B). First, the magnitude of the changes was much smaller. The decrease in the share of private employees after 1961, for example, was

${ }^{25}$ These findings are robust to alternative definitions of innovation (Table A16, columns 3 and 4 ) and to their estimation on the smaller sample of matched individuals (Table A16, panel B). Moreover, the same correlations hold between occupations and the probability of innovating in more traditional STEM fields (identified in Section 5; Table A16, columns 5 and 6)

${ }^{26}$ In panel A of Figure 4, the blue bars represent the difference between the share of post-reform industrial students with a STEM degree and the share of pre-reform industrial students in each occupation. The red bars denote the innovation propensity of different jobs, measured as the share of inventors out of the total number of workers employed in each occupation.

${ }^{27}$ The production of patents in STEM fields (Section 5) is even more concentrated in just a few job categories (Figure A5). 
equal to only 3.4 percentage points, instead of 5.3 percentage points for industrial students with a STEM degree. Second, industrial students who did not receive a STEM degree after 1961 moved to different occupations, such as entrepreneurship, local public institutions, the entertainment industry, and the health sector. The stark differences between panels A and B of Figure 4 confirm that the occupational sorting of industrial students with STEM degrees is likely not the result of secular changes in the Italian economy, but rather a direct consequence of the expanded access into STEM majors.

We can further highlight the role played by this job shift on innovation outcomes by including occupational variables in equation (1). In particular, we regress the innovative output of individual $i$ in calendar year $y$ on the usual set of treatment variables (Industrial ${ }_{i} \times$ Post $_{t}$ ), as well as their interaction with the occupation held in year $y$ (Industrial ${ }_{i} \times \operatorname{Post}_{t} \times$ Occupation $\left._{y}\right){ }^{28}$ These specifications suggest that the industrial students who chose lowinnovation jobs after the reform were more likely to experience larger decreases in their probability of producing patents. In the matched sample, for example, the patenting probability of industrial students increased by 1.46 percentage points between 1961 and 1964, and did not change significantly between 1965 and 1973 (Table A17, panel B, column 1). ${ }^{29}$ The effect, however, is large in magnitude and negative among industrial students who decided to become self-employed engineers after receiving a university-level STEM degree. Among this group, the patenting probability decreased by additional 1.56 percentage points between 1961 and 1964, by additional 0.57 percentage points between 1965 and 1968, and by additional 0.26 percentage points between 1969 and 1973. This finding is even clearer among industrial students with lower precollegiate ability. In this case, the average probability of producing patents significantly increased after receiving access to university-level STEM education, but did not change among the university graduates who decided to become self-employed engineers (Table A17, panel B, column 3). The same pattern is present for other occupations that do not traditionally focus on innovation, such as other self-employed jobs and many public positions (Table A17, columns 4 to 9).

\subsection{Heterogeneous Occupational Changes}

So far, the analysis suggested that there is a strong bond between jobs and patenting and that occupational choices changed after the reform of university admissions. Specifically,

\footnotetext{
${ }^{28}$ We also control for all other regressors in equation (1), as well as calendar year fixed effects.

${ }^{29}$ As in the previous analysis, the treatment effects refer to cohorts of high school graduation, not to calendar years. The phrase "between 1961 and 1964," for example, identifies the average change in the yearly probability of patenting for the cohorts who completed high school between 1961 and 1964, considering all calendar years in the dataset.
} 
industrial students left innovation-centric positions, such as high-skilled workers in manufacturing firms, in favor of newly-accessible jobs in sectors that do not focus on the production of innovation. In the rest of the analysis, we show that this occupational shift was more prominent among higher-achieving industrial students, thus contributing to explain their lower probability of innovating after the reform. In these specifications, we regress the occupation held by individual $i$ in year $y$ on the usual set of difference-in-differences variables $\left(\right.$ Industrial $_{i} \times$ Post $_{t}$ ), all the controls in equation (1), and calendar year fixed effects.

After 1961 industrial students in the top quartile of pre-collegiate achievement were more likely to become self-employed engineers, a profession with a relatively low level of innovation propensity. More specifically, the probability of working as a self-employed engineer increased by 1.2 percentage points between 1961 and 1968, and by 1.3 percentage points between 1969 and 1973 (Table 5, panel A, column 1). The effects are larger if we consider other forms of self-employed professionals (Table 5, panel A, column 2). There is no evidence, however, that higher-achieving industrial students disproportionally entered into highly innovative occupations, in spite of an increase in the number of STEM degrees after 1961 (Table 5, panel A, columns 3 and 4). ${ }^{30}$ The data for industrial students who scored in the bottom three quartiles of pre-collegiate achievement do not indicate any significant increase in the probability of working as a self-employed engineer. Especially after 1965, the estimated effects are a precisely estimated zero (Table 5, panel A, column 5). ${ }^{31}$ Overall, these findings are in line with the observed changes in innovation propensity. Many higher-achieving students moved to jobs that became available only after receiving access to university-level STEM education, but that did not produce many patents, such as self-employed engineers and other professions. In contrast, lower-achieving students remained employed in manufacturing, one of the more active sectors in producing patents.

Why was this occupational shift concentrated among higher-achieving students? First, the target occupations had significant barriers to entry. Self-employed engineers, for example, must complete a university STEM degree and pass a national examination. Similarly, public servants are chosen through lengthy screening, in which academic achievements are usually part of the selection criteria. These requirements could make these professions

\footnotetext{
${ }^{30}$ The estimated decrease in employment share is the result of a slight increase among industrial students that is outpaced by a larger rise among academic students. Similarly, the difference-in-differences estimate of becoming a public employee is negative due to higher entry over time among academic students (not reported).

${ }^{31}$ The results are robust if we re-estimate these specifications on the smaller sample of matched students with a STEM degree (Table 5, panel B). Moreover, multinomial logit (Table A18) and IV (Table A19) estimations (in place of an OLS) confirm the main findings. Differently from other industrial students, top industrial students became more likely to become self-employed professionals (occupations with relatively low propensity to innovate) after receiving a STEM degree.
} 
more attractive to individuals with higher ability. Second, the high variance of returns in self-employment might deter lower-achieving students, who might find advantageous that firms in the private sector cannot adjust wages below minimum thresholds agreed with the unions. Third, by forcing a worker to repeatedly establish new business relationships, selfemployment might make it harder to overcome the weak signal provided by poor academic achievement. This can be especially true in the Italian labor market, in which the final high school ("voto di maturità") and university ("voto di laurea") scores are very salient to prospective employers.

Even though there can be multiple reasons for higher-achieving STEM graduates to shift towards non-innovative occupations, earnings data indicate that the monetary compensation of industrial students increased at every level of precollegiate ability. Income from employed work and self-employment of industrial students increased by 9.7 percent between 1961 and 1964, by 16.1 percent between 1965 and 1968, and by 8.6 percent between 1969 and 1973 , compared with academic students (Table A20, panel A, column 1). ${ }^{32}$ The estimated coefficients are economically significant for both higher-achieving and lower-achieving industrial students, but they are statistically significant only for the latter group (Table A20, panel A, columns 2 and 3). This increase does not stem exclusively from shifts across occupations, but also from gains within a given job category. To show this, we use as dependent variable the difference between the individual income and the average income in a given occupation. The income of industrial students increased from the occupational average by 10.9 percent between 1961 and 1964, by 16.9 percent between 1965 and 1968, and by 13.6 percent between 1969 and 1973 (Table A20, panel A, column 4). Estimates by levels of precollegiate ability leads to similar conclusions, although the coefficients tend to be larger in magnitude for lower-achieving industrial students. ${ }^{33}$

\subsection{Changes within the Private Sector}

In this section, we leverage additional information that is available only for employees in the private sector. We describe two main findings. First, lower-achieving industrial students remained employed in the innovation-centric manufacturing sector, even after completing STEM degrees. Second, university-level education allowed them to reach higher-ranked positions that were more central in the development of innovation. These are potential

\footnotetext{
${ }^{32}$ INPS data do not have any information about work income of public employees, pharmacists, and notaries. Therefore, individuals holding these positions are not included in this analysis.

${ }^{33}$ Table A1 and Figure A6 have additional information about the distribution of income from employment and self-employment across different occupations.
} 
mechanisms through which the propensity to innovate might have increased after the reform among workers who decided to stay in high-innovation jobs.

As described above for broader job categories, there is a strong correlation between economic sectors (Italian ATECO 91 categorization) and the propensity to innovate. Relative to manufacturing, the probability of producing patents is 0.43 percentage points lower in the energy sector, 0.29 percentage points lower in the construction industry, 0.31 percentage points lower in retail, and 0.38 percentage points lower in finance (Table A21, panel A, column $1)$. These coefficients suggest that the innovation propensity in these industries was between 83 and 123 percent lower than the baseline yearly patenting probability (0.35 percent). Therefore, any education policy that triggers sectoral changes might have consequences on the probability of innovating. Simple cross-sectional graphs indicate that many industrial students with STEM university-level degrees did not necessarily move to innovation-intensive sectors after the reform (Figure A7).

We then analyze in a difference-in-differences setting how industrial students with STEM degrees sorted into different sectors after the reform. We regress the sector of employment of individual $i$ in year $y$ on the usual set of difference-in-differences variables (Industrial ${ }_{i} \times$ Post $_{t}$ ), all the controls in equation (1), and calendar year fixed effects. Many higher-achieving industrial students left manufacturing, a high-innovation sector, but did not move into R\&D, another industry heavily focusing on the production of patents(Table A22, panel B, columns 1 and2). Their likelihood of being employed in a high-paying industry, however, increased by 8.3 percentage points between 1965 and 1968, and by 8.6 percentage points between 1969 and 1973 (Table A22, panel B, column 3). These sectors are the five industries with the highest average salaries for workers with STEM degrees (energy, food/hospitality, transportation/communications, finance/banking, and international organizations), even though they do not focus on the production of patents. In contrast, lower-achieving industrial students either stayed in manufacturing or moved to other innovative sectors, such as R\&D (Table A22, panel B, columns 4 and 5).

There might be several reasons behind these heterogeneous findings. Non-STEM economic sectors hiring STEM skills might lack the tools to properly evaluate STEM graduates. Therefore, they might be more likely to use academic achievements as an objective signal of quality of job candidates with STEM degrees. This hiring policy would induce more higher-achieving students to seek high-paying job opportunities outside more traditional STEM fields. In addition, higher ability might allow higher-achieving STEM students to perform better in areas in which they are not directly prepared by their university studies. These considerations do not imply that higher-achieving students were the only group that benefitted from the reform. On average, in fact, work-related income of industrial students 
increased by 12.2 percent between 1961 and 1964, by 19.5 percent between 1965 and 1968, and by 17.3 percent between 1969 and 1973, compared with academic students (Table A23, panel A, column 1). These effects hold at any level of precollegiate ability, even though they are more precisely estimated for lower-achieving industrial students. ${ }^{34}$

In addition to analyzing sectoral changes, we can study how the roles held by industrial students changed after receiving higher-level university degrees. In Italian private-sector firms, there are seven formal positions with increasing responsibilities: apprentices, bluecollar, high-skilled blue-collar ("intermedi"), white-collar, high-skilled white-collar ( "quadri"), and managers. The data indicate the existence of a strong bond between different positions and the probability of producing patents. More specifically, higher-ranked positions have a higher propensity to innovate. The probability of producing patents, for example, is 0.3 percentage points higher among managers, compared with lower-ranked employees (Table A24, panel A, column 1). This coefficient represent a 150 percent increase in innovation from a baseline patenting probability of just 0.2 percent. This correlation holds even after controlling for completed education (Table A24, panel A, column 2), but is larger in magnitude among individuals with lower precollegiate ability (0.3 vs. 0.2 percentage points for higher-achieving students; not reported). This finding might suggest that higherachieving individuals were more likely to patent when they occupied lower-ranked positions.

Cross-sectional evidence clearly indicates that industrial students with a STEM degree became more likely to hold managerial jobs after the reform (Figure A8, panel A). The same pattern is not present among industrial students without a STEM degree, suggesting that the previous finding is unlikely to confound other changes in the Italian labor market that are not related to the education reform (Figure A8, panel B). We replicate this analysis with difference-in-differences specifications. We regress dummies measuring the position held individual $i$ in year $y$ on the usual set of difference-in-differences variables (Industrial ${ }_{i} \times$ Post $_{t}$ ), all the controls in equation (1), and calendar year fixed effects. All industrial students became more likely to work in higher-ranked positions after 1961, but the effect is larger among lowerachieving students (Table A25). If we include industry fixed effects, the coefficients estimated on the sample of matched students remain large and statistically significant, suggesting that the role changes were realized mainly through upwards movements within the same industries (Table A25, panel B, columns 3 and 7).

These results indicate that the reform might have caused industrial students to have more successful careers within the private sector. By becoming more likely to reach managerial positions in manufacturing firms, industrial students also became more likely to be directly

${ }^{34}$ Within each sector, their income increase by 10.7 percent from the sectoral average between 1965 and 1969 (Table A23, panel A, column 4). 
involved in the innovation processes. In other words, among the industrial students who did not switch towards non-innovative occupations or sector, the education reform increased the patenting propensity.

\section{Conclusions}

In this paper, we study how graduating in a STEM major affects the probability of becoming an inventor. Thanks to the historical setting, we can estimate the long-run causal effect of scientific education on the amount and direction of innovation. Moreover, the richness of the administrative data allows us to link the main findings to changes in the external and internal labor markets.

We find two sets of direct effects of scientific education on patenting activity. First, students who received a university STEM degree became more likely to patent in STEM-oriented fields, such as medicine, chemistry, and IT. Second, students with a STEM degree who found employment in privately owned firms became more likely to hold managerial positions, in which they became more involved in the production of patents. On the extensive margin, however, we also find that scientific education changes sorting into innovative occupations. Some higher-achieving students used their newly acquired STEM degree to enter occupations that could not previously be accessed with only a high school diploma and that did not focus on the production of patents.

These findings depict a complex relationship between education and innovation, which is mediated by the characteristics of the local labor market. To the best of our knowledge, this paper is the first to document how individual-level investments in human capital affect innovation propensity through changes in occupational sorting. We believe that the mechanisms discussed in this paper apply beyond the Italian setting. In many developed countries, STEM skills are now sought after by industries that do not focus on the production of patents, such as finance. According to the US Census Bureau, for example, 74 percent of STEM graduates are not employed in a STEM occupation (Census Bureau, 2014). Any effort to encourage innovation by increasing the number of STEM graduates would need to take into account how these students sort into non-STEM jobs.

Moreover, the Italian reform might be directly informative about other large-scale plans to increase scientific skills in the developing world (for example, UNESCO's Science Education Program). Many developing countries, in fact, are now facing the same issue that induced the Italian government to change enrollment requirements in 1961: they must increase the number of university-educated workers to sustain industrial growth. This paper indicates that these reforms might change the direction of innovation and the selection of individuals 
in innovation-centric jobs. The Italian experience also suggests that an increase in university STEM education could possibly steer some graduates away from innovative jobs, if demand for university-level STEM skills is strong in other sectors of the economy (even where there is not a large financial sector attracting STEM talent, as in the Italian case).

\section{References}

Aghion, Philippe, Ufuk Akcigit, Ari Hyytinen, and Otto Toivanen. 2017. "The Social Origins and IQ of Inventors." NBER Working Paper 24110.

Akcigit, Ufuk, John Grigsby, and Tom Nicholas. 2017. "The Rise of American Ingenuity: Innovation and Inventors of the Golden Age." NBER Working Paper \# 23047.

Andrews, Michael. 2019. "How Do Institutions of Higher Education Affect Local Invention? Evidence from the Establishment of U.S. Colleges." working paper, NBER.

Baumol, William J. 1990. "Entrepreneurship : Productive, Unproductive, and Destructive." Journal of Political Economy, 98(5): 893-921.

Bell, Alex, Raj Chetty, Xavier Jaravel, Neviana Petkova, and John Van Reenen. 2018. "Who Becomes an Inventor in America? The Importance of Exposure to Innovation." Quarterly Journal of Economics, forthcoming.

Bianchi, Nicola. 2019. "The Indirect Effects of Educational Expansions: Evidence from a Large Enrollment Increase in University Majors." working paper, Northwestern University.

Borjas, George J., and Kirk B. Doran. 2012. "The Collapse of the Soviet Union and the Productivity of American Mathematicians." Quarterly Journal of Economics, 127(3): 1143-1203.

Buonanno, Paolo, and Leone Leonida. 2009. "Non-market effects of education on crime: Evidence from Italian regions." Economics of Education Review, 28(1): 11-17.

Cantoni, Davide, and Noam Yuchtman. 2014. "Medieval Universities, Legal Institutions, and the Commercial Revolution." Quarterly Journal of Economics, 129(2): 823-887.

Card, David. 1999. "The Causal Effect of Education on Earnings." In Handbook of Labor Economics. Vol. 5, , ed. Orley Ashenfelter and David Card, 1801-1863. New York:NorthHolland.

Card, David. 2001. "Estimating the Return to Schooling: Progress on Some Persistent Econometric Problems." Econometrica, 69(5): 1127-1160.

Carnevale, Anthony P., Nicole Smith, and Michelle Melton. 2011. "STEM." Georgetown University Center on Education and the Workforce.

Census Bureau. 2014. "Majority of STEM College Graduates Do Not Work in STEM Occupations." Census Bureau Report CB14-130.

Cook, Philip J., and Songman Kang. 2016. "Birthdays, schooling, and crime: Regression-discontinuity analysis of school performance, delinquency, dropout, and crime initiation." American Economic Journal: Applied Economics, 8(1): 33-57.

Copeland, M. A. 1937. "Concepts of National Income." In Studies in Income and Wealth. Vol. 1, ed. The Conference on Research in Income and Wealth, 3-63. NBER.

Cutler, David M., and Adriana Lleras-Muney. 2010. "Understanding differences in health behaviors by education." Journal of Health Economics, 29(1): 1-28. 
Dee, Thomas S. 2004. "Are there civic returns to education?" Journal of Public Economics, 88(9-10): 1697-1720.

Depalo, Domenico, and Sabrina Di Addario. 2014. "Inventors' Returns to Patents." Development Studies Working Papers 375.

de Walque, Damien. 2010. "Education, Information, and Smoking Decisions. Evidence from Smoking Histories, 1940-2000." Journal of Human Resources, 45(3): 682-717.

DiNardo, John, Nicole M. Fortin, and Thomas Lemieux. 1996. "Labor Market Institutions and The Distribution of Wages, 1973 - 1992: A Semiparametric Approach." Econometrica, 64(5): 1001 - 1044.

Eide, Eric R., and Mark H. Showalter. 2011. "Estimating the relation between health and education: What do we know and what do we need to know?" Economics of Education Review, 30(5): 778-791.

Giuri, Paola, Myriam Mariani, Stefano Brusoni, Gustavo Crespi, Dominique Francoz, Alfonso Gambardella, Walter Garcia-Fontes, Aldo Geuna, Raul Gonzales, Dietmar Harhoff, Karin Hoisl, Christian Le Bas, Alessandra Luzzi, Laura Magazzini, Lionel Nesta, Önder Nomaler, Neus Palomeras, Pari Patel, Marzia Romanelli, and Bart Verspagen. 2007. "Inventors and invention processes in Europe: Results from the PatVal-EU survey." Research Policy, 36(8): 1107-1127.

Griliches, Zvi. 1990. "Patent Statistics as Economic Indicators: A Survey." Journal of Economic Literature, 28(4): 1661-1707.

Griliches, Zvi. 1996. "The Discovery of the Residual: An Historical Note." Journal of Economic Literature, 34(3): 1324-1330.

Grossman, Michael. 2006. "Education and Nonmarket Outcomes." In Handbook of the Economics of Education. Vol. 1, Chapter 10, 577-633.

Hall, Bronwyn H. 2011. "Innovation and productivity." Nordic Economic Policy Conference on Productivity and Competition.

Hall, Bronwyn H., Adam B. Jaffe, and Manuel Trajtenberg. 2001. "The NBER Patent Citations Data File: Lessons, Insights and Methodological Tools." NBER Working Paper 8498.

Istituto Nazionale di Statistica. n.d.. Annuario Statistico dell'Istruzione Italiana. Anni 1955-1975. Roma.

Jung, Taehyun, and Olof Ejermo. 2014. "Demographic patterns and trends in patenting: Gender, age, and education of inventors." Technological Forecasting and Social Change, 86: $110-124$.

Lleras-Muney, Adriana. 2005. "The relationship between education and adult mortality in the United States." Review of Economic Studies, 72(January): 189-221.

Lochner, Lance J. 2004. "Education, work, and crime: A human capital approach." International Economic Review, 45(3): 811-843.

Lochner, Lance J., and Enrico Moretti. 2004. "The effect of education on crime: Evidence from prison inmates, arrests, and self-reports." American Economic Review, 94(1): 155-189.

Lockwood, Benjamin B., Charles G. Nathanson, and E. Glen Weyl. 2017. "Taxation and the Allocation of Talent." Journal of Political Economy, , (October): forthcoming.

Meghir, Costas, and Steven Rivkin. 2011. "Econometric Methods for Research in Education." In Handbook of the Economics of Education. Vol. 3. 1 ed., 1-87. Elsevier 
Ltd.

Milligan, Kevin, Enrico Moretti, and Philip Oreopoulos. 2004. "Does education improve citizenship? Evidence from the United States and the United Kingdom." Journal of Public Economics, 88(9-10): 1667-1695.

Moser, Petra, Alessandra Voena, and Fabian Waldinger. 2014. "German Jewish Émigrés and US Invention." American Economic Review, 104(10): 3222-3255.

Murphy, Kevin M., Andrei Shleifer, and Robert W. Vishny. 1991. "The Allocation of Talent: Implication for Growth." The Quarterly Journal of Economics, 106(2): 503-530.

Peri, Giovanni, Kevin Shih, and Chad Sparber. 2015. "STEM Workers, H-1B Visas, and Productivity in US Cities." Journal of Labor Economics, 33(S1): S225-S255.

Philippon, Thomas. 2010. "Financiers versus Engineers: Should the Financial Sector be Taxed or Subsidized?" American Economic Journal: Macroeconomics, 2(3): 158-182.

President's Council of the Advisors on Science and Technology. 2012. "Engage to Excel: Producing One Million Additional College Graduates with Degrees in Science, Technology, Engineering, and Mathematics."

Shu, Pian. 2016. "Innovating in Science and Engineering or "Cashing In" on Wall Street? Evidence on Elite STEM Talent." Harvard Business School Working Paper 16-067.

Silles, Mary A. 2009. "The causal effect of education on health: Evidence from the United Kingdom." Economics of Education Review, 28(1): 122-128.

Solow, Robert M. 1957. "Technical Change and the Aggregate Production Function." The Review of Economics and Statistics, 39(3): 312.

Toivanen, Otto, and Lotta Väänänen. 2016. "Education and Invention." Review of Economics and Statistics, 98(2): 382-396.

Trajtenberg, Manuel. 1990. "A penny for your quotes: patent citations and the value of innovations." The RAND Journal of Economics, 21(1): 172-187.

Wantchekon, Leonard, Marko Klasnja, and Natalija Novta. 2015. "Education and Human Capital Externalities: Evidence from Colonial Benin." The Quarterly Journal of Economics, 130(2): 703-757.

Webbink, Dinand, Nicholas G. Martin, and Peter M. Visscher. 2010. "Does education reduce the probability of being overweight?" Journal of Health Economics, 29(1): 29-38. 


\section{Figures and Tables}

Figure 1: Differential Increase in Graduation Rates from University STEM Majors

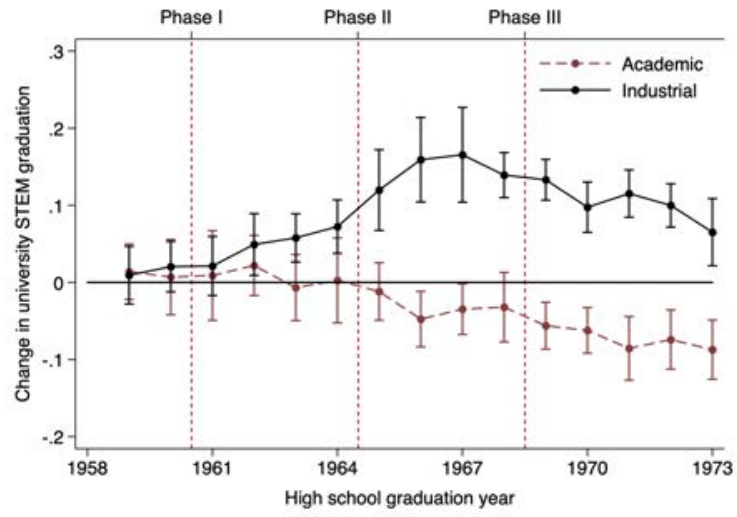

A. Industrial vs. Academic Students

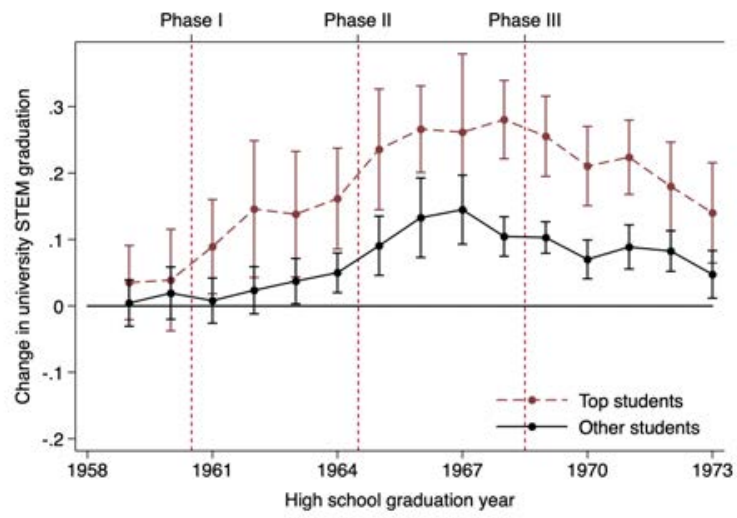

C. Top vs. Other Industrial Students

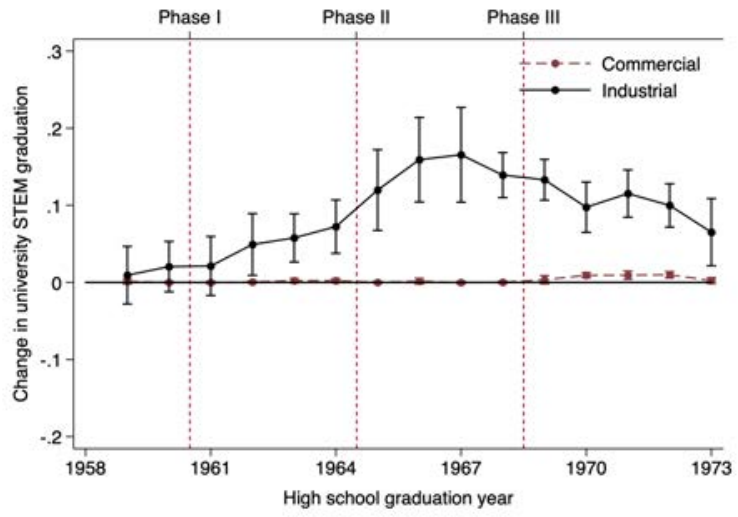

B. Industrial vs. Commercial Students

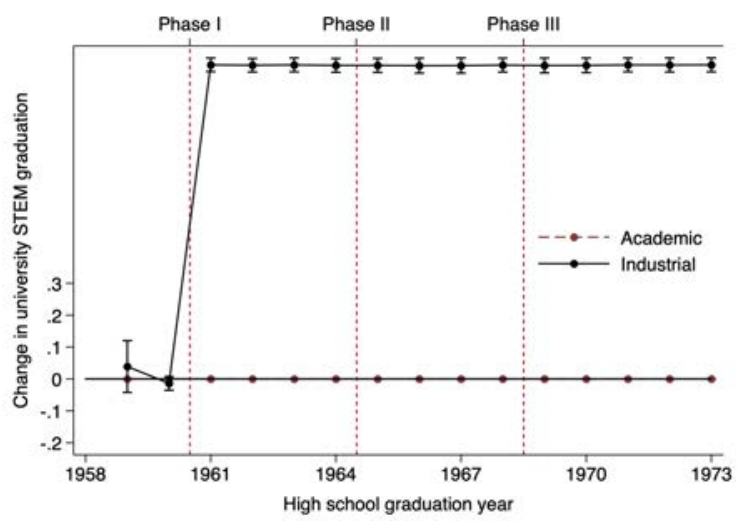

D. Matched Industrial vs. Academic Students

Notes: This graph shows the change (and 95 percent CIs) in the graduation rate from university STEM majors for different groups of students. Industrial students could enroll in STEM majors for the first time in 1961. During phase I, industrial students faced enrollment caps in STEM majors. During phase II, industrial students could freely enroll in STEM majors. During phase III, students had more freedom in the choice of the university curriculum. Academic students (panel A) had access to STEM majors throughout the time period under analysis. Commercial students (panel B) could not enroll in university STEM majors until 1969, when any high school diploma started granting access to all majors. Top industrial students (panel C) received a final high school grade in the top quartile of their school distribution. Panel D uses propensity score matching to identify a subgroup of academic and industrial students in the pre-period with the same observable characteristics of students in the post-period with a STEM degree. The regressions control for gender, province of birth fixed effects, high school fixed effects, the high school standardized score, the average standardized score of the closest peers in high school, a dummy for home-schooled students, and a dummy for students who graduated high school at 19 (and likely never repeated a grade). Standard errors clustered by school and cohort. 
Figure 2: Distribution of Inventors across Technological Fields

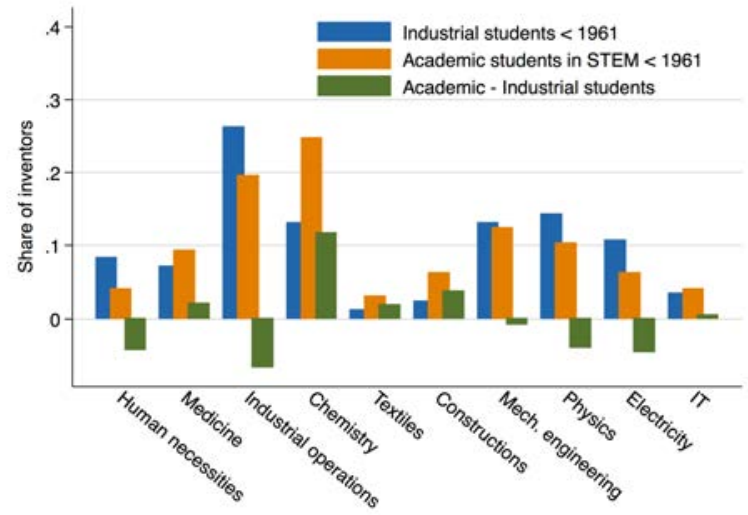

A. Academic Students with STEM Degree vs. Industrial Students Before 1961

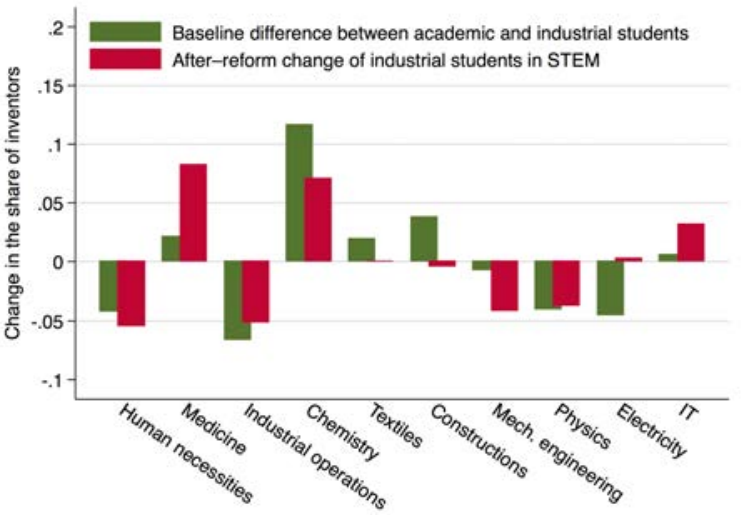

B. After-reform Change for Industrial Students with a STEM Degree

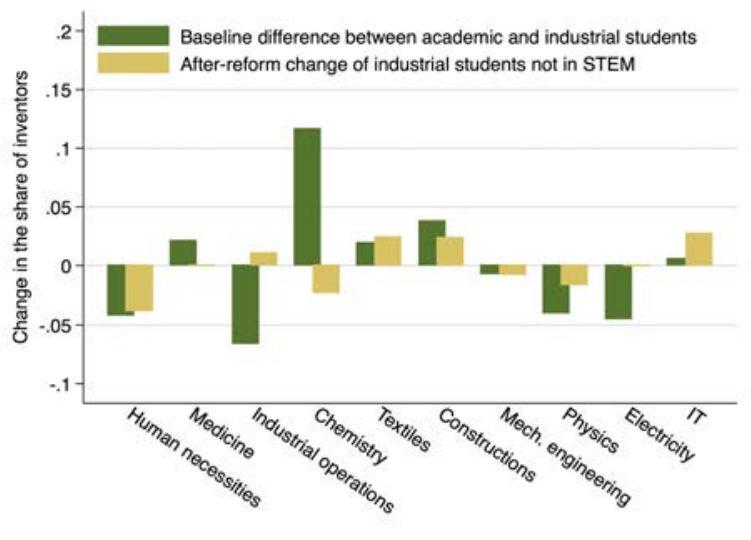

C. After-reform Change for Industrial Students without a STEM Degree

Notes: These graphs show the distribution of inventors across different technological fields. Panel A shows the pre-reform distribution of academic students with a STEM degree and industrial students across technological fields. Panel B shows the post-reform change for industrial students who received a STEM degree after 1961. Panel C shows the post-reform change for industrial students who did not receive a STEM degree after 1961. 
Figure 3: Cross-Cohort Change in Inventor Share

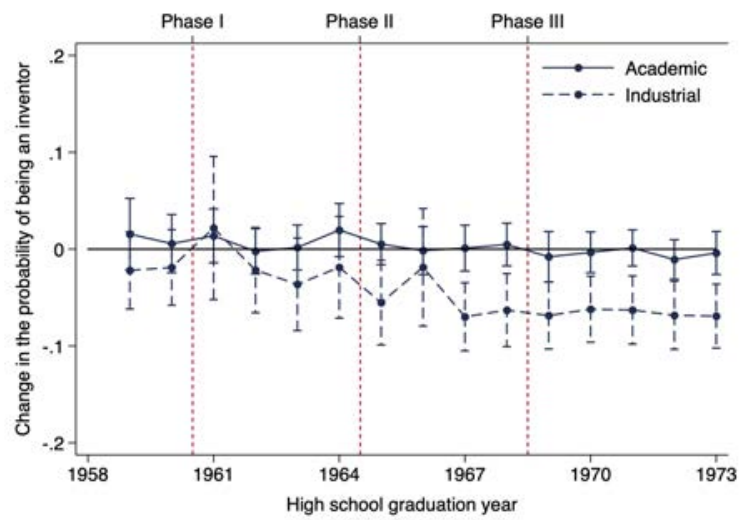

A. Top Industrial vs. Top Academic Students

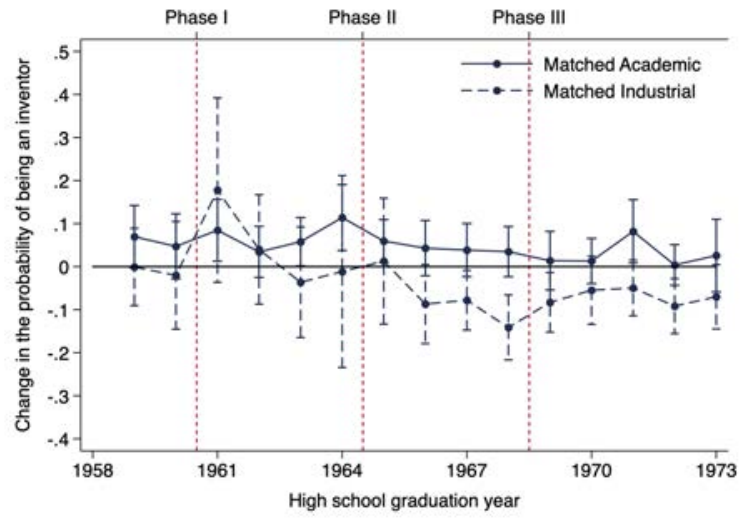

C. Top Matched Industrial vs. Academic Students

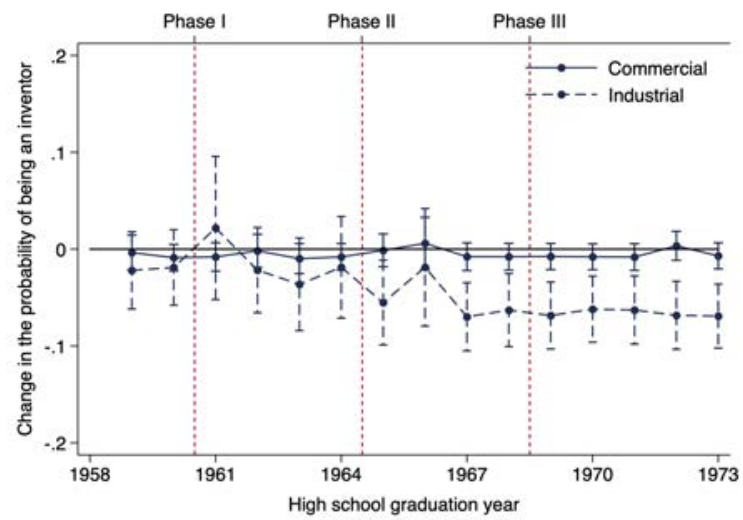

B. Top Industrial vs. Top Commercial Students

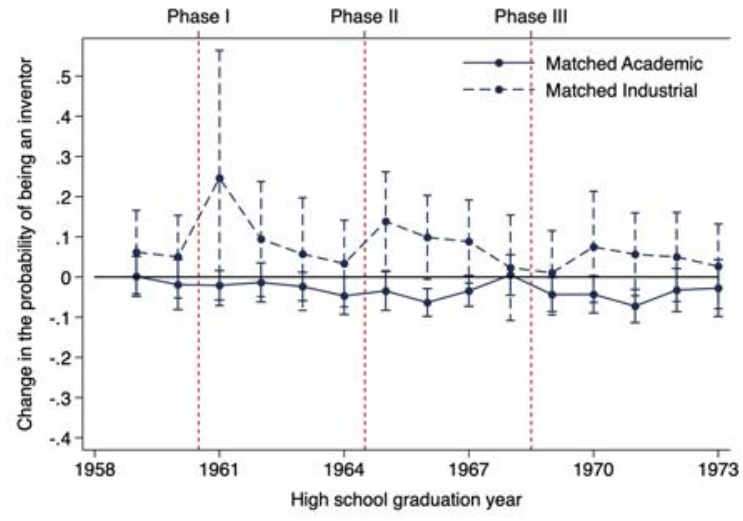

D. Other Matched Industrial vs. Academic Students

Notes: This graph shows the change (and 95 percent CIs) in the inventor share across subsequent cohorts for different groups of students. Industrial students could enroll in STEM majors for the first time in 1961. During phase I, industrial students faced enrollment caps in STEM majors. During phase II, industrial students could freely enroll in STEM majors. During phase III, students had more freedom to choose the university curriculum. Academic students (panel A) had access to STEM majors throughout the time period under analysis. Commercial students (panel B) could not enroll in university STEM majors until 1969, when any high school diploma started granting access to all majors. Panel $\mathrm{C}$ uses propensity score matching to identify a subgroup of top academic and industrial students in the pre-period with the same observable characteristics of top students in the post-period with a STEM degree. Top students received a final high school grade in the top quartile of their school distribution. Panel D shows results on matched industrial and academic students who did not score in the top quartile of their high school class in the final high school exam. The regressions control for gender, province of birth fixed effects, high school fixed effects, the high school standardized score, the average standardized score of the closest peers in high school, a dummy for home-schooled students, and a dummy for students who graduated high school at 19 (and likely never repeated a grade). Standard errors clustered by school and cohort. 
Figure 4: Distribution of Inventors across Occupations

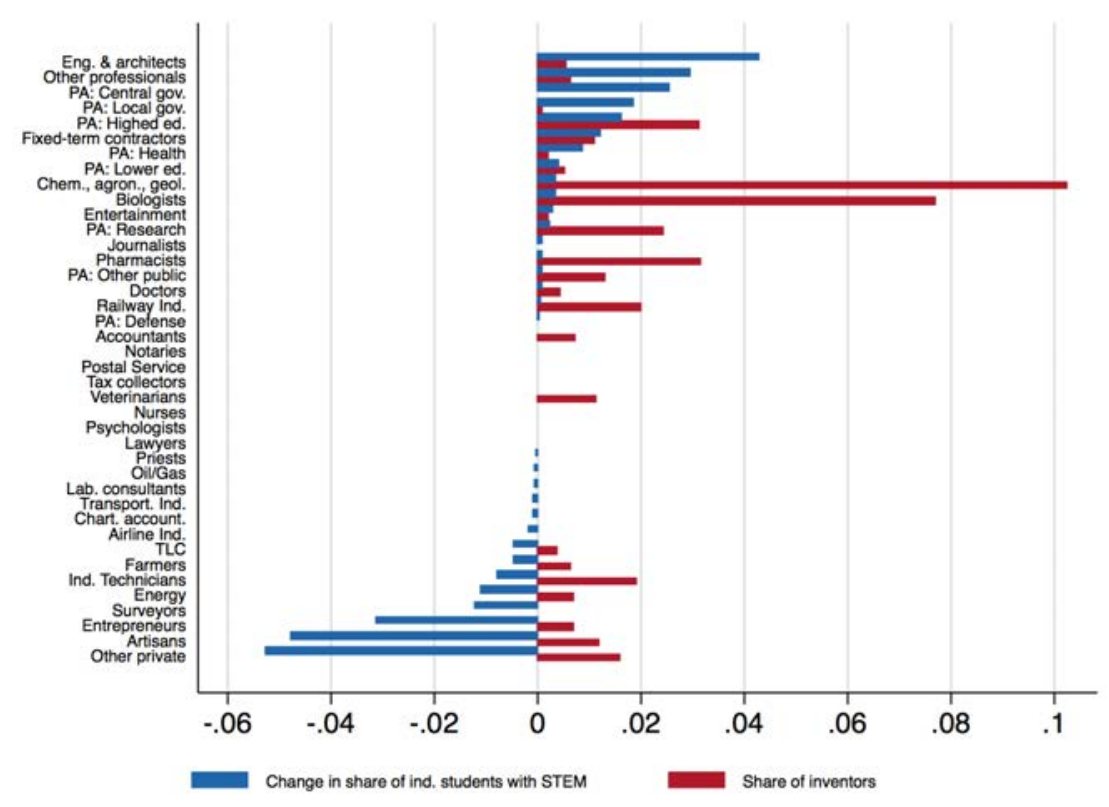

A. Change for Industrial Students with a STEM Degree

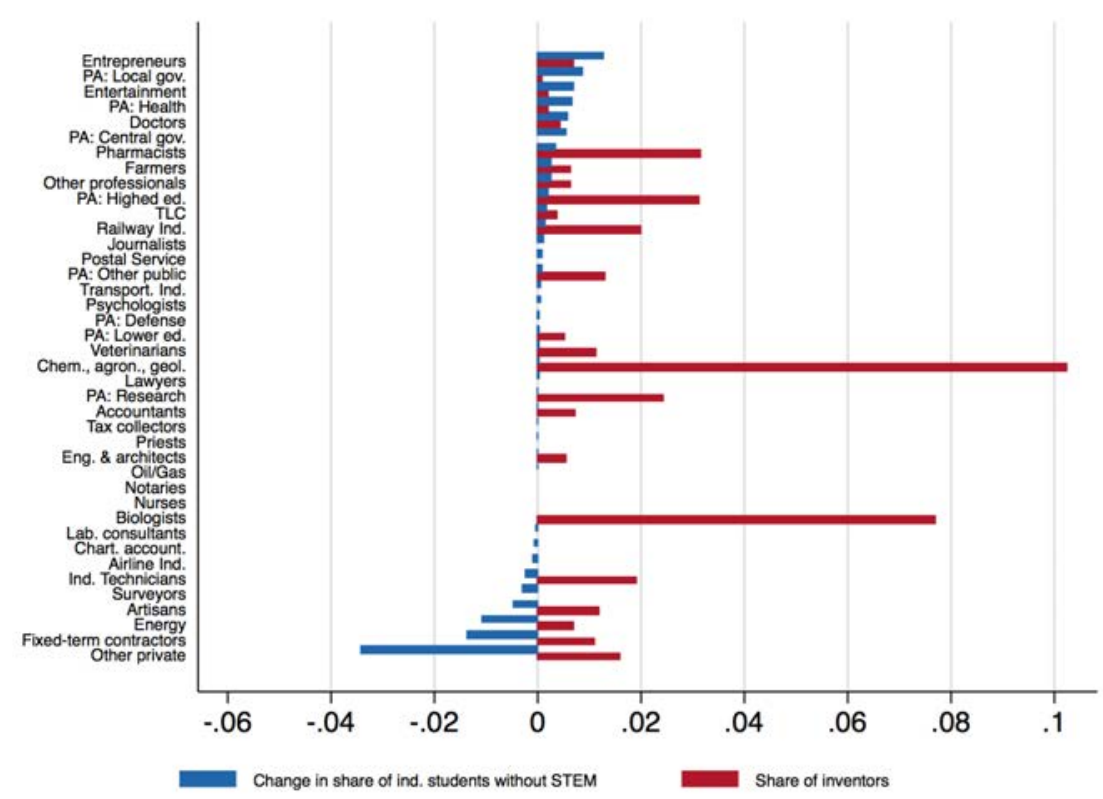

\section{B. Change for Industrial Students without a STEM Degree}

Notes: These graphs show how the distribution of industrial students across different occupations changed among the cohorts who completed high school after 1961. Panel A shows how the distribution of industrial students who received a STEM degree after 1961 changed, relative to the pre-reform distribution. Panel B shows how the distribution of industrial students who did not receive a STEM degree after 1961 changed, relative to the pre-reform distribution. Share of inventors measures the percentage of inventors in each occupation, pooling all available years of patent data (1968-2010). 
Table 1: Summary Statistics

\begin{tabular}{|c|c|c|c|}
\hline & $\begin{array}{l}\text { Inventors } \\
\text { (1) }\end{array}$ & $\begin{array}{l}\text { Non-inventors } \\
\qquad(2)\end{array}$ & $\begin{array}{c}\text { Difference } \\
(3)\end{array}$ \\
\hline Observations & 869 & 45,604 & \\
\hline Male & 0.962 & 0.721 & $0.241^{* * *}$ \\
\hline Birth year & 1945.44 & 1946.29 & $-0.855^{* *}$ \\
\hline \multicolumn{4}{|l|}{ Patent data } \\
\hline Number of patents & 4.010 & - & - \\
\hline Number of technological fields & 1.478 & - & - \\
\hline \multicolumn{4}{|l|}{ Education data } \\
\hline Academic diploma & 0.320 & 0.409 & $-0.089^{* * *}$ \\
\hline Industrial diploma & 0.641 & 0.351 & $0.290^{* * *}$ \\
\hline HS exit score & 0.256 & -0.005 & $0.261^{* * *}$ \\
\hline Score of HS peers & 0.009 & 0.000 & 0.009 \\
\hline Home schooled & 0.043 & 0.102 & $-0.059^{* * *}$ \\
\hline Non-repeater & 0.959 & 0.930 & $0.028^{* * *}$ \\
\hline Enrolled & 0.653 & 0.568 & $0.084^{* * *}$ \\
\hline Enrolled in a STEM major & 0.490 & 0.192 & $0.299^{* * *}$ \\
\hline University degree & 0.479 & 0.343 & $0.136^{* * *}$ \\
\hline University STEM degree & 0.392 & 0.125 & $0.267^{* * *}$ \\
\hline \multicolumn{4}{|l|}{ Labor market outcomes } \\
\hline Private employees & 0.936 & 0.885 & $0.051^{* * *}$ \\
\hline Researchers & 0.026 & 0.015 & $0.011^{* *}$ \\
\hline Manufacturing* & 0.838 & 0.521 & $0.317^{* * *}$ \\
\hline $\mathrm{R} \& \mathrm{D}^{*}$ & 0.023 & 0.009 & $0.014^{* *}$ \\
\hline Managers* & 0.556 & 0.292 & $0.264^{* * *}$ \\
\hline Highly skilled white collar* & 0.209 & 0.154 & $0.055^{* * *}$ \\
\hline
\end{tabular}

Notes: The sample is composed of 46,473 individuals who completed high school in Milan between 1958 and 1973. The high school score is the grade received on the high school final exam. It is standardized by cohort and high school. The HS peers are groups of 20-30 students within a cohort attending all lectures together. Home-schooled students took only the final exam in the school, even though they studied elsewhere during the regular school year. They could be enrolled in private schools that could not administer the final exam or they could be home-educated. Non-repeaters were 19 years old at the time of the final exam (the standard age of high school graduation). STEM majors are engineering, physics, mathematics, biology, geology, natural science, and chemistry. Researchers are employees of institutions of higher education. $\left(^{*}\right)$ These variables are available only for employees in the private sector and only starting in 1983.

Sources: High school archives; university transcripts; patents issued by the Italian patent office between 1968 and 2010; international patents collected by the European Patent Office's PATSTAT database; social security data. 
Table 2: Pre-Reform Trends in Innovative Activity

\begin{tabular}{|c|c|c|c|c|c|c|c|c|}
\hline & $\begin{array}{c}\text { Inventor } \\
\text { (1) }\end{array}$ & $\begin{array}{c}\text { Inventor } \\
(2)\end{array}$ & $\begin{array}{c}\text { Patents } \\
(3)\end{array}$ & $\begin{array}{c}\text { Patents } \\
(4)\end{array}$ & $\begin{array}{c}\text { Inventor } \\
(5)\end{array}$ & $\begin{array}{c}\text { Inventor } \\
(6)\end{array}$ & $\begin{array}{c}\text { Patents } \\
(7)\end{array}$ & $\begin{array}{c}\text { Patents } \\
(8)\end{array}$ \\
\hline \multicolumn{9}{|c|}{ Panel A: Individual-level regressions } \\
\hline Industrial $x$ Linear trend & $\begin{array}{c}-0.0026 \\
(0.0038)\end{array}$ & & $\begin{array}{c}-0.0393 \\
(0.0400)\end{array}$ & & $\begin{array}{l}-0.0050 \\
(0.0327)\end{array}$ & & $\begin{array}{c}-0.0129 \\
(0.2151)\end{array}$ & \\
\hline Industrial x 1959 & & $\begin{array}{c}0.0029 \\
(0.0078)\end{array}$ & & $\begin{array}{l}-0.0701 \\
(0.0712)\end{array}$ & & $\begin{array}{c}0.0032 \\
(0.0527)\end{array}$ & & $\begin{array}{c}0.2855 \\
(0.4985)\end{array}$ \\
\hline Industrial x 1960 & & $\begin{array}{l}-0.0052 \\
(0.0076)\end{array}$ & & $\begin{array}{c}-0.0789 \\
(0.0801)\end{array}$ & & $\begin{array}{l}-0.0104 \\
(0.0651)\end{array}$ & & $\begin{array}{l}-0.0403 \\
(0.4105)\end{array}$ \\
\hline Observations & 4,430 & 4,430 & 4,430 & 4,430 & 683 & 683 & 683 & 683 \\
\hline $\mathrm{R}^{2}$ & 0.0393 & 0.0394 & 0.0202 & 0.0203 & 0.0614 & 0.0614 & 0.0344 & 0.0350 \\
\hline $1959 \neq 1960$ & & 0.418 & & 0.576 & & 0.959 & & 0.657 \\
\hline Matched sample & & & & & $\checkmark$ & $\checkmark$ & $\checkmark$ & $\checkmark$ \\
\hline \multicolumn{9}{|c|}{ Panel B: Class-quartile of high school score regressions } \\
\hline Industrial $x$ Linear trend & $\begin{array}{l}-0.0109 \\
(0.0674)\end{array}$ & & $\begin{array}{c}-0.0589 \\
(0.0909)\end{array}$ & & $\begin{array}{c}-0.0001 \\
(0.0691)\end{array}$ & & $\begin{array}{c}-0.2119 \\
(0.1665)\end{array}$ & \\
\hline Industrial x 1959 & & $\begin{array}{l}-0.0007 \\
(0.1184)\end{array}$ & & $\begin{array}{c}-0.0587 \\
(0.1870)\end{array}$ & & $\begin{array}{c}0.1135 \\
(0.1578)\end{array}$ & & $\begin{array}{l}-0.0508 \\
(0.4981)\end{array}$ \\
\hline Industrial x 1960 & & $\begin{array}{l}-0.0222 \\
(0.1351)\end{array}$ & & $\begin{array}{l}-0.1178 \\
(0.1817)\end{array}$ & & $\begin{array}{l}-0.0169 \\
(0.1174)\end{array}$ & & $\begin{array}{c}-0.4704^{*} \\
(0.2670)\end{array}$ \\
\hline Observations & 756 & 756 & 756 & 756 & 316 & 316 & 316 & 316 \\
\hline $\mathrm{R}^{2}$ & 0.0142 & 0.0147 & 0.0072 & 0.0072 & 0.0143 & 0.0216 & 0.0042 & 0.0098 \\
\hline $1959 \neq 1960$ & & 0.983 & & 0.795 & & 0.752 & & 0.23 \\
\hline Matched sample & & & & & $\checkmark$ & $\checkmark$ & $\checkmark$ & $\checkmark$ \\
\hline \multicolumn{9}{|c|}{ Panel C: High school-quartile of high school score regressions } \\
\hline Industrial $x$ Linear trend & $\begin{array}{c}-0.0050 \\
(0.5339)\end{array}$ & & $\begin{array}{l}-0.0457 \\
(0.1547)\end{array}$ & & $\begin{array}{c}-0.1061 \\
(0.2172)\end{array}$ & & $\begin{array}{c}-0.2340 \\
(0.2553)\end{array}$ & \\
\hline Industrial x 1959 & & $\begin{array}{c}0.0625 \\
(1.0949)\end{array}$ & & $\begin{array}{l}-0.0554 \\
(0.3154)\end{array}$ & & $\begin{array}{c}0.1297 \\
(0.4862)\end{array}$ & & $\begin{array}{r}0.0535 \\
(0.5294)\end{array}$ \\
\hline Industrial x 1960 & & $\begin{array}{c}-0.0083 \\
(1.0759)\end{array}$ & & $\begin{array}{c}-0.0914 \\
(0.3108)\end{array}$ & & $\begin{array}{l}-0.2101 \\
(0.4137)\end{array}$ & & $\begin{array}{l}-0.4647 \\
(0.4702)\end{array}$ \\
\hline Observations & 119 & 119 & 119 & 119 & 90 & 90 & 90 & 90 \\
\hline $\mathrm{R}^{2}$ & 0.0268 & 0.0282 & 0.0386 & 0.0387 & 0.0031 & 0.0172 & 0.0359 & 0.0504 \\
\hline $1959 \neq 1960$ & & 0.997 & & 0.957 & & 0.758 & & 0.614 \\
\hline Matched sample & & & & & $\checkmark$ & $\checkmark$ & $\checkmark$ & $\checkmark$ \\
\hline
\end{tabular}

Notes: This table tests for the existence of parallel pre-reform trends in innovative activities between industrial and academic students. Panel A estimates individual level regressions. The dependent variables are a dummy equal to 1 for individuals who developed at least one patent (columns 1, 2, $5,6)$ and the number of developed patents (columns 3, 4, 7,8). The sample comprises all industrial and academic students who completed high school before 1961 (columns 1-4) or just the subsample of matched individuals (columns 5-8) . The regressions also include cohort fixed effects, gender, province of birth fixed effects, high school fixed effects, the high school standardized score, the average standardized score of the closest peers in high school, a dummy for home-schooled students, and a dummy for students who graduated high school at 19 (and likely never repeated a grade). In panel $\mathrm{B}$, the unit of observation is a pre-reform cohort of high school graduation (between 1958 and 1960)-high school class (small groups of 20-30 students)-quartile of pre-collegiate achievement combination. The dependent variables are the inventor count (columns 1, 2, 5,6) and the average number of patents (columns 3, 4, 7, 8). The regressions also include cohort fixed effects and the dummy "Industrial" not interacted. In panel C, the unit of observation is a pre-reform cohort of high school graduation (between 1958 and 1960)-high school-quartile of pre-collegiate achievement combination. All other features of these regressions are unchanged from panel B. Standard errors clustered by high school and cohort in parentheses, ${ }^{* * *} \mathrm{p}<0.01,{ }^{* *} \mathrm{p}<0.05,{ }^{*} \mathrm{p}<0.1$. 
Table 3: Type of Innovation

\begin{tabular}{|c|c|c|c|c|c|c|}
\hline & $\begin{array}{l}\text { STEM field } \\
\text { (1) }\end{array}$ & $\begin{array}{l}\text { STEM field } \\
(2)\end{array}$ & $\begin{array}{l}\text { STEM field } \\
\text { (3) }\end{array}$ & $\begin{array}{l}\text { STEM field } \\
\text { (4) }\end{array}$ & $\begin{array}{l}\text { STEM field } \\
\text { (5) }\end{array}$ & $\begin{array}{l}\text { STEM field } \\
\text { (6) }\end{array}$ \\
\hline \multicolumn{7}{|c|}{ Panel A: Industrial vs. academic students } \\
\hline Industrial x Post 1961 & $\begin{array}{c}0.1485 \\
(0.0930)\end{array}$ & $\begin{array}{c}0.1406 \\
(0.0925)\end{array}$ & $\begin{array}{c}0.2948 \\
(0.1994)\end{array}$ & $\begin{array}{c}0.2230 \\
(0.2361)\end{array}$ & $\begin{array}{c}0.0145 \\
(0.1376)\end{array}$ & $\begin{array}{c}0.0199 \\
(0.1285)\end{array}$ \\
\hline Industrial x Post 1965 & $\begin{array}{c}0.2637^{* * *} \\
(0.0864)\end{array}$ & $\begin{array}{c}0.2609^{* * *} \\
(0.0869)\end{array}$ & $\begin{array}{c}0.2874 \\
(0.2192)\end{array}$ & $\begin{array}{c}0.1870 \\
(0.2451)\end{array}$ & $\begin{array}{l}0.2369^{*} \\
(0.1229)\end{array}$ & $\begin{array}{c}0.2871^{* *} \\
(0.1243)\end{array}$ \\
\hline Industrial x Post 1969 & $\begin{array}{c}0.2145^{* *} \\
(0.0988)\end{array}$ & $\begin{array}{c}0.2810^{* * *} \\
(0.0926)\end{array}$ & $\begin{array}{l}0.3979^{*} \\
(0.2366)\end{array}$ & $\begin{array}{c}0.3228 \\
(0.2405)\end{array}$ & $\begin{array}{c}0.0989 \\
(0.1196)\end{array}$ & $\begin{array}{l}0.1926^{*} \\
(0.1137)\end{array}$ \\
\hline \multicolumn{7}{|c|}{ Panel B: Matched, Industrial vs. academic students } \\
\hline Industrial x Post 1961 & $\begin{array}{c}0.1557 \\
(0.1571)\end{array}$ & $\begin{array}{c}0.0890 \\
(0.1482)\end{array}$ & $\begin{array}{c}0.3657 \\
(0.3738)\end{array}$ & $\begin{array}{c}0.1666 \\
(0.4129)\end{array}$ & $\begin{array}{l}-0.0423 \\
(0.2963)\end{array}$ & $\begin{array}{c}0.0582 \\
(0.2863)\end{array}$ \\
\hline Industrial x Post 1965 & $\begin{array}{c}0.6997^{* * *} \\
(0.1627)\end{array}$ & $\begin{array}{c}0.6773^{* * *} \\
(0.1563)\end{array}$ & $\begin{array}{c}0.5784 \\
(0.3855)\end{array}$ & $\begin{array}{c}0.3130 \\
(0.3810)\end{array}$ & $\begin{array}{c}0.7473^{* * *} \\
(0.2208)\end{array}$ & $\begin{array}{c}0.7417^{* * *} \\
(0.2019)\end{array}$ \\
\hline Industrial x Post 1969 & $\begin{array}{c}0.4672^{* * *} \\
(0.1728)\end{array}$ & $\begin{array}{c}0.5070^{* * *} \\
(0.1665)\end{array}$ & $\begin{array}{c}0.7695^{* *} \\
(0.3584)\end{array}$ & $\begin{array}{l}0.6805^{*} \\
(0.3660)\end{array}$ & $\begin{array}{l}0.4265^{*} \\
(0.2179)\end{array}$ & $\begin{array}{c}0.4613^{* *} \\
(0.2021)\end{array}$ \\
\hline Sample & All & All & Top & Top & Other & Other \\
\hline STEM fields & Three & Five & Three & Five & Three & Five \\
\hline Pre-reform dep. var. (panel A) & 0.3676 & 0.3971 & 0.2800 & 0.3200 & 0.4186 & 0.4419 \\
\hline Pre-reform dep. var. (panel B) & 0.2857 & 0.2857 & 0.3000 & 0.3000 & 0.2500 & 0.2500 \\
\hline Observations (panel A) & 818 & 818 & 241 & 241 & 577 & 577 \\
\hline Observations (panel B) & 310 & 310 & 118 & 118 & 192 & 192 \\
\hline
\end{tabular}

Notes. This table shows changes in the type of innovation. Columns 1 and 2 show estimates using the whole sample, columns 3 and 4 use only students in the top quartile of the ability distribution, and columns 5 and 6 use only the students in the bottom three quartiles of the ability distribution. The dependent variable is a dummy that equals 1 if the individual patented at least once in a STEM field. In columns 1, 3, and 5, the STEM fields are medicine, chemistry, and IT. In columns 2, 4, and 6, the STEM fields are medicine, chemistry, textiles, constructions, and IT. Standard errors clustered by high school and cohort in parentheses, ${ }^{* * *} \mathrm{p}<0.01,{ }^{* *} \mathrm{p}<0.05,{ }^{*} \mathrm{p}<0.1$. 
Table 4: Probability of Becoming an Inventor, Industrial vs. Academic Students

\begin{tabular}{|c|c|c|c|c|c|c|}
\hline & $\begin{array}{l}\text { Inventor } \\
(1)\end{array}$ & $\begin{array}{l}\text { Inventor } \\
(2)\end{array}$ & $\begin{array}{l}\text { Inventor } \\
(3)\end{array}$ & $\begin{array}{l}\text { Inventor } \\
\text { (4) }\end{array}$ & $\begin{array}{l}\text { Inventor } \\
(5)\end{array}$ & $\begin{array}{l}\text { Inventor } \\
(6)\end{array}$ \\
\hline \multicolumn{7}{|c|}{ Panel A: Industrial vs. academic students } \\
\hline Industrial x Post 1961 & $\begin{array}{l}-0.0004 \\
(0.0066)\end{array}$ & $\begin{array}{l}-0.0033 \\
(0.0091)\end{array}$ & $\begin{array}{l}-0.0002 \\
(0.0172)\end{array}$ & $\begin{array}{l}-0.0066 \\
(0.0213)\end{array}$ & $\begin{array}{l}-0.0011 \\
(0.0059)\end{array}$ & $\begin{array}{l}-0.0041 \\
(0.0110)\end{array}$ \\
\hline Industrial x Post 1965 & $\begin{array}{l}0.0035 \\
(0.0059)\end{array}$ & $\begin{array}{l}0.0005 \\
(0.0088)\end{array}$ & $\begin{array}{l}-0.0317^{* *} \\
(0.0144)\end{array}$ & $\begin{array}{c}-0.0381^{*} \\
(0.0193)\end{array}$ & $\begin{array}{l}0.0122^{* *} \\
(0.0061)\end{array}$ & $\begin{array}{l}0.0093 \\
(0.0111)\end{array}$ \\
\hline Industrial x Post 1969 & $\begin{array}{l}-0.0109^{* *} \\
(0.0052)\end{array}$ & $\begin{array}{c}-0.0138^{*} \\
(0.0083)\end{array}$ & $\begin{array}{l}-0.0403^{* * *} \\
(0.0120)\end{array}$ & $\begin{array}{l}-0.0467^{* * *} \\
(0.0177)\end{array}$ & $\begin{array}{l}-0.0028 \\
(0.0053)\end{array}$ & $\begin{array}{l}-0.0058 \\
(0.0108)\end{array}$ \\
\hline Industrial x Pre-reform trend & & $\begin{array}{l}-0.0029 \\
(0.0060)\end{array}$ & & $\begin{array}{l}-0.0060 \\
(0.0128)\end{array}$ & & $\begin{array}{l}-0.0029 \\
(0.0069)\end{array}$ \\
\hline \multicolumn{7}{|c|}{ Panel B: Matched, Industrial vs. academic students } \\
\hline Industrial x Post 1961 & $\begin{array}{l}0.0412 \\
(0.0377)\end{array}$ & $\begin{array}{l}0.0440 \\
(0.0449)\end{array}$ & $\begin{array}{l}-0.0044 \\
(0.0501)\end{array}$ & $\begin{array}{l}-0.0219 \\
(0.0554)\end{array}$ & $\begin{array}{l}0.0664^{*} \\
(0.0387)\end{array}$ & $\begin{array}{l}0.1120^{* *} \\
(0.0512)\end{array}$ \\
\hline Industrial x Post 1965 & $\begin{array}{l}0.0225 \\
(0.0248)\end{array}$ & $\begin{array}{l}0.0253 \\
(0.0341)\end{array}$ & $\begin{array}{l}-0.0679^{* *} \\
(0.0334)\end{array}$ & $\begin{array}{l}-0.0854^{* *} \\
(0.0410)\end{array}$ & $\begin{array}{l}0.0795^{* * *} \\
(0.0292)\end{array}$ & $\begin{array}{l}0.1252^{* * *} \\
(0.0448)\end{array}$ \\
\hline Industrial x Post 1969 & $\begin{array}{l}-0.0001 \\
(0.0215)\end{array}$ & $\begin{array}{l}0.0027 \\
(0.0319)\end{array}$ & $\begin{array}{l}-0.0629^{* *} \\
(0.0296)\end{array}$ & $\begin{array}{l}-0.0806^{* *} \\
(0.0378)\end{array}$ & $\begin{array}{l}0.0532^{*} \\
(0.0272)\end{array}$ & $\begin{array}{l}0.0991 * * \\
(0.0435)\end{array}$ \\
\hline Industrial x Pre-reform trend & & $\begin{array}{l}0.0030 \\
(0.0262)\end{array}$ & & $\begin{array}{l}-0.0209 \\
(0.0339)\end{array}$ & & $\begin{array}{l}0.0408 \\
(0.0283)\end{array}$ \\
\hline Sample & All & All & Top & Top & Other & Other \\
\hline Pre-reform inventor share (panel A) & 0.0427 & 0.0427 & 0.0740 & 0.0740 & 0.0346 & 0.0346 \\
\hline Pre-reform inventor share (panel B) & 0.0897 & 0.0897 & 0.1176 & 0.1176 & 0.0563 & 0.0563 \\
\hline Observations (panel A) & 35,479 & 35,479 & 7,662 & 7,662 & 27,817 & 27,817 \\
\hline Observations (panel B) & 4,718 & 4,718 & 1,807 & 1,807 & 2,911 & 2,911 \\
\hline
\end{tabular}

Notes. This table shows the effect of the promotion of STEM education on the probability of becoming an inventor by comparing industrial to academic students (panel A), and matched industrial to academic students (panel B). The matching selects students in the pre-period who share the same observable characteristics of individuals with a STEM degree in the post-period. The dependent variable, Inventor, is a dummy that equals 1 for students who patented at least once from 1968 to 2010. Post 1961 is 1 for cohorts who graduated between 1961 and 1964, Post 1965 is 1 for cohorts who graduated between 1965 and 1968, and Post 1969 is 1 for cohorts who graduated between 1969 and 1973. Pre-reform trend is a linear trend for pre-reform cohorts. Columns 3 and 4 restrict the sample to students who ranked in the top quartile of their school's grade distribution. Columns 5 and 6 restrict the sample to students who are not in the top ability quartile. The regressions also include cohort fixed effects, gender, province of birth fixed effects, high school fixed effects, the high school standardized score, the average standardized score of the closest peers in high school, a dummy for home-schooled students, and a dummy for students who graduated high school at 19 (and likely never repeated a grade). Standard errors clustered by high school and cohort in parentheses, ${ }^{* * *} \mathrm{p}<0.01,{ }^{* *} \mathrm{p}<0.05,{ }^{*} \mathrm{p}<0.1$. 
Table 5: Changes in Occupation

\begin{tabular}{|c|c|c|c|c|c|c|c|c|}
\hline & $\begin{array}{l}\text { Engineers } \\
\text { (1) }\end{array}$ & $\begin{array}{l}\text { S-e prof. } \\
(2)\end{array}$ & $\begin{array}{l}\text { Top occ. } \\
(3)\end{array}$ & $\begin{array}{l}\text { Researchers } \\
\text { (4) }\end{array}$ & $\begin{array}{l}\text { Engineers } \\
\text { (5) }\end{array}$ & $\begin{array}{l}\text { S-e prof. } \\
(6)\end{array}$ & $\begin{array}{l}\text { Top occ. } \\
(7)\end{array}$ & $\begin{array}{l}\text { Researchers } \\
(8)\end{array}$ \\
\hline \multicolumn{9}{|c|}{ Panel A: Industrial vs. academic students } \\
\hline Industrial x Post 1961 & $\begin{array}{l}0.0120^{* *} \\
(0.0058)\end{array}$ & $\begin{array}{l}0.0150^{*} \\
(0.0080)\end{array}$ & $\begin{array}{l}-0.0308^{* * *} \\
(0.0092)\end{array}$ & $\begin{array}{l}-0.0314^{* * *} \\
(0.0093)\end{array}$ & $\begin{array}{l}-0.0050^{* *} \\
(0.0023)\end{array}$ & $\begin{array}{l}-0.0079^{* *} \\
(0.0034)\end{array}$ & $\begin{array}{l}-0.0057^{* *} \\
(0.0029)\end{array}$ & $\begin{array}{l}-0.0062^{* *} \\
(0.0024)\end{array}$ \\
\hline Industrial x Post 1965 & $\begin{array}{l}0.0120^{* *} \\
(0.0061)\end{array}$ & $\begin{array}{l}0.0200^{* *} \\
(0.0082)\end{array}$ & $\begin{array}{l}-0.0595^{* * *} \\
(0.0110)\end{array}$ & $\begin{array}{l}-0.0539^{* * *} \\
(0.0109)\end{array}$ & $\begin{array}{l}-0.0007 \\
(0.0023)\end{array}$ & $\begin{array}{l}-0.0028 \\
(0.0033)\end{array}$ & $\begin{array}{l}-0.0155^{* * *} \\
(0.0036)\end{array}$ & $\begin{array}{l}-0.0170^{* * *} \\
(0.0032)\end{array}$ \\
\hline Industrial x Post 1969 & $\begin{array}{l}0.0128^{* *} \\
(0.0061)\end{array}$ & $\begin{array}{l}0.0212^{* * *} \\
(0.0079)\end{array}$ & $\begin{array}{l}-0.0259^{* * *} \\
(0.0072)\end{array}$ & $\begin{array}{l}-0.0248^{* * *} \\
(0.0070)\end{array}$ & $\begin{array}{l}-0.0006 \\
(0.0024)\end{array}$ & $\begin{array}{l}0.0002 \\
(0.0033)\end{array}$ & $\begin{array}{l}-0.0113^{* * *} \\
(0.0030)\end{array}$ & $\begin{array}{l}-0.0076^{* * *} \\
(0.0021)\end{array}$ \\
\hline \multicolumn{9}{|c|}{ Panel B: Matched, Industrial vs. academic students } \\
\hline Industrial x Post 1961 & $\begin{array}{l}0.0442^{* * *} \\
(0.0160)\end{array}$ & $\begin{array}{l}0.0638^{* * *} \\
(0.0196)\end{array}$ & $\begin{array}{l}0.0056 \\
(0.0258)\end{array}$ & $\begin{array}{l}-0.0119 \\
(0.0256)\end{array}$ & $\begin{array}{l}0.0019 \\
(0.0109)\end{array}$ & $\begin{array}{l}-0.0020 \\
(0.0167)\end{array}$ & $\begin{array}{l}0.0528^{*} \\
(0.0317)\end{array}$ & $\begin{array}{l}0.0497 \\
(0.0314)\end{array}$ \\
\hline Industrial x Post 1965 & $\begin{array}{l}0.0222^{*} \\
(0.0120)\end{array}$ & $\begin{array}{l}0.0352^{* *} \\
(0.0153)\end{array}$ & $\begin{array}{l}-0.0052 \\
(0.0228)\end{array}$ & $\begin{array}{l}0.0003 \\
(0.0232)\end{array}$ & $\begin{array}{l}-0.0054 \\
(0.0081)\end{array}$ & $\begin{array}{l}-0.0093 \\
(0.0121)\end{array}$ & $\begin{array}{l}-0.0021 \\
(0.0120)\end{array}$ & $\begin{array}{l}-0.0023 \\
(0.0120)\end{array}$ \\
\hline Industrial x Post 1969 & $\begin{array}{l}0.0052 \\
(0.0132)\end{array}$ & $\begin{array}{l}0.0240 \\
(0.0150)\end{array}$ & $\begin{array}{l}-0.0453^{* * *} \\
(0.0149)\end{array}$ & $\begin{array}{l}-0.0410^{* *} \\
(0.0160)\end{array}$ & $\begin{array}{l}-0.0221^{* *} \\
(0.0099)\end{array}$ & $\begin{array}{c}-0.0226^{*} \\
(0.0129)\end{array}$ & $\begin{array}{l}0.0055 \\
(0.0085)\end{array}$ & $\begin{array}{l}0.0033 \\
(0.0077)\end{array}$ \\
\hline Sample & Top & Top & Top & Top & Other & Other & Other & Other \\
\hline Pre-reform dep. var. (panel A) & 0.000 & 0.009 & 0.000 & 0.000 & 0.002 & 0.008 & 0.000 & 0.000 \\
\hline Pre-reform dep. var. (panel B) & 0.000 & 0.004 & 0.000 & 0.000 & 0.000 & 0.007 & 0.000 & 0.000 \\
\hline Observations (panel A) & 234,961 & 234,961 & 234,961 & 234,961 & 802,657 & 802,657 & 802,657 & 802,657 \\
\hline Observations (panel B) & 59,122 & 59,122 & 59,122 & 59,122 & 93,272 & 93,272 & 93,272 & 93,272 \\
\hline
\end{tabular}

Notes. This table shows the effect of the promotion of STEM education on the occupation choice. Engineers is 1 for freelance professional engineers (occupation "Engineers" in Table A1); S-e prof. is 1 for self-employed professionals ("Engineers" + "Other professionals" in Table A1); Top Occ. is a dummy for the top 10 percent occupations in terms of share of inventors: self-employed biologists, self-employed chemists, pharmacists, and public employees of institutions of higher education ("Biologists" + "Chem., agron., geol." + "Pharmacists" + "PA: Higher ed." in Table A1); Researchers is 1 for research-intensive occupations in institutions of higher education ("PA: Higher ed." in Table A1). Post 1961 is 1 for cohorts who graduated between 1961 and 1964, Post 1965 is 1 for cohorts who graduated between 1965 and 1968, and Post 1969 is 1 for cohorts who graduated between 1969 and 1973. Columns 1 to 4 restrict the sample to students who ranked in the top quartile of their school's grade distribution. Columns 5 to 8 restrict the sample to students who ranked in the bottom three quartiles of their school's grade distribution. The regressions include cohort and calendar year fixed effects, gender, province of birth fixed effects, high school fixed effects, the HS score, the average standardized score of the closest peers in high school, a dummy for home-schooled students, and a dummy for students who graduated high school at 19. Standard errors clustered by student in parentheses, ${ }^{* *} \mathrm{p}<0.01,{ }^{* *} \mathrm{p}<0.05,{ }^{*} \mathrm{p}<0.1$. 